\title{
ANATOMI DAN KUALITAS SERAT LIMA JENIS KAYU KURANG DIKENAL DARI LENGKONG, SUKABUMI
}

\section{(Anatomy and Fiber Quality of Five Lesser Known Wood Species from Lengkong, Sukabumi)}

\author{
Oleh/By : \\ Krisdianto ${ }^{1)}$
}

\begin{abstract}
Lesser known wood species could be one of the possible wood sources available to fulfil the need of wood-industries. Anatomical characteristics and fiber quality of five wood species from Lengkong, Sukabumi have been studied for wood identification and utilisation purposes. The main characteristics of five wood species described are:

1. Ki hantap (Sterculia oblongata R.Br.) wood is greyish yellow, large rays distinct forming line configuration on surface, growth ring distinct formed by bandparenchyma. Aliform parenchyma and diffuse-in-aggregates found. Rays in two distinct sizes.

2. Ki kuya (Ficus vasculosa Wall. ex Miq.) wood is bright yellow, growth ring clearly distinct formed by wide band parenchyma. This parenchyma forms white line configuration on wood surface.

3. Ki lubang (Calophyllum grandiflorum J.J.S.) wood is brown reddish and grouped as 'bintangor', that have been traded commercially. Vessel of this wood is in group and arranged in radial or diagonalpattern.

4. Ki bancet (Turpinia sphaerocarpa Hassk.) wood is yellowish, moderatively light. Growth ring is indistinct, vessel relatively abundant and small in size, ray in two distinct sizes.

5. Ki bulu (Gironniera subaequalis Planch.) wood is white yellowish and moderately hard. Growth rings are clearly distinct, formed by narrow bandparenchyma and differences of fiber thickness. Ray in two distinct sizes.
\end{abstract}

Fiber quality of five wood studied classified as very good (first quality) forpulp and paper.

Keywords: Five, anatomy, wood, identification, fiber

\begin{abstract}
ABSTRAK
Sumber bahan baku alternatif untuk industri perkayuan nasional saat ini dan masa yang akan datang berasal dari hutan tanaman dan pemanfaatan jenis kayu kurang dikenal. Dalam pemanfaatan kayu kurang dikenal diperlukan informasi struktur anatomi dan kualitas seratnya untuk keperluan pengenalan jenis dan pemanfaatannya.
\end{abstract}

${ }^{1)}$ Peneliti pada Pusat Penelitian dan Pengembangan Hasil Hutan, Bogor 
Untuk keperluan identifikasi, ciri utama dari kelima jenis tersebut adalah :

1. Kayu ki hantap (Sterculia oblongata R.Br.) berwarna kuning keabu-abuan, corak bergaris, dengan lingkaran tumbuh jelas oleh parenkim pita. Parenkim bentuk sayap, dan difus berkelompok, jari-jari 2 ukuran.

2. Kayu ki kuya (Ficus vasculosa Wall. ex Miq.) berwarna kuning cerah, lingkaran tumbuh jelas oleh parenkim pita. Parenkim pita tebal membentuk corak garis-garis putih pada produk kayunya.

3. Kayu ki lubang (Calophyllum grandiflorum J.J.S.) berwarna coklat kemerahan dan termasuk dalam kelompok kayu perdagangan bintangur. Pembuluh kayu ki lubang bersusun dalam kelompok radial atau diagonal dan parenkim pita memanjang yang kadang terputus.

4. Kayu ki bancet (Turpinia sphaerocarpa Hassk.) berwarna kekuningan, agak lunak. Lingkaran tumbuh kayu ki bancet kurang jelas, pembuluhnya agak banyak dan berukuran agak kecil, jari-jari 2 macam ukuran.

5. Kayu ki bulu (Gironniera subaequalis Planch.) berwarna kuning keputihan dan agak keras. Lingkaran tumbuhnya jelas oleh adanya parenkim pita tipis dan perbedaan ketebalan dinding selnya, jari-jari 2 ukuran.

Serat kelima jenis kayu termasuk dalam kelas kualitas I sebagai bahan baku pulp untuk kertas.

Kata kunci : Lima, anatomi, kayu, identifikasi, serat

\section{PENDAHULUAN}

Salah satu permasalahan mendasar yang dihadapi oleh industri perkayuan saat ini adalah kurangnya pasokan bahan baku kayu. Tim kerjasama pendataan antara Departemen Kehutanan dan Departemen Perindustrian dan Perdagangan pada tahun 2004 melaporkan bahwa jumlah Industri Primer Hasil Hutan Kayu (IPHHK) mencapai 1.540 unit, dengan kebutuhan kayu diperkirakan 63,48 juta $\mathrm{m}^{3}$ per tahun (Laban, 2005, Wargadalam, 2005). Untuk menghindari kebangkrutan industri perkayuan nasional, maka Departemen Kehutanan mengarahkan peran hutan tanaman sebagai pemasok bahan baku kayu untuk industri. Selain itu, industri pengolahan kayu juga disarankan untuk memanfaatkan jenis-jenis kayu yang selama ini kurang dikenal.

Indonesia memiliki banyak jenis pohon berkayu, diperkirakan mencapai lebih dari 4000 jenis (Martawijaya et al., 1981). Menurut Martawijaya dan Kartasudjana (1977) hanya sekitar 400 jenis yang sudah dikenal dalam perdagangan serta memiliki nama dagang tertentu. Jenis kayu lain umumnya dikenal dalam perdagangan dengan istilah "racuk", yaitu kayu campuran atau kayu sembarang. Hal ini menunjukkan keterbatasan pengetahuan masyarakat perkayuan mengenai material kayu.

Sebelum memanfaatkan kayu, pengguna memerlukan data dan informasi jenis serta sifat dasar lainnya, sehingga alokasi pemanfaatannya sesuai dengan karkateristik kayunya. Dalam hal ini identifikasi kayu merupakan proses awal untuk menentukan jenis pemanfaatan kayu. Tulisan ini bertujuan mempelajari sifat anatomi lima jenis kayu kurang dikenal dari Lengkong, Sukabumi untuk mendukung identifikasi jenis dan kualitas serat kayunya. 


\section{BAHAN DAN METODE}

Lima jenis kayu kurang dikenal dikumpulkan dari kawasan hutan di Lengkong, Jawa Barat. Identifikasi herbarium kelima jenis pohon tersebut dilakukan oleh Kelompok Peneliti Botani, Pusat Penelitian dan Pengembangan Hutan dan Konservasi Alam, Bogor. Jenis-jenis kayu yang dipelajari dan nomor koleksinya dalam Xylarium Bogorensis dan kelas awetnya serta kelas kuatnya menurut Oey Djoen Seng (1964) ditampilkan dalam Tabel 1.

\section{Tabel 1. Jenis kayu yang dipelajari dan kelas awet serta kelas kuatnya} Table 1. Durability and strength classes of the studied species

\begin{tabular}{|c|c|c|c|c|c|}
\hline $\begin{array}{c}\text { No. } \\
\text { koleksi } \\
\text { (Collection } \\
\text { No.) }\end{array}$ & $\begin{array}{c}\text { Nama } \\
\text { Lokal } \\
\text { (Local } \\
\text { name) }\end{array}$ & $\begin{array}{l}\text { Nama ilmiah } \\
\text { (Scientific name) }\end{array}$ & $\begin{array}{l}\text { Marga } \\
\text { (Family) }\end{array}$ & $\begin{array}{c}\text { K. awet } \\
\text { (Durability } \\
\text { class) }\end{array}$ & $\begin{array}{c}\text { K. kuat } \\
\text { (Strength } \\
\text { class) }\end{array}$ \\
\hline 34311 & Ki hantap & Sterculia oblongata R.Br. & Sterculiaceae & $\mathrm{V}$ & IV - III \\
\hline 34312 & Ki kuya & Ficus vasculosa Wall.ex Miq. & Moraceae & $\mathrm{V}$ & IV $-\mathrm{V}$ \\
\hline 34313 & Ki lubang & Calophyllum grandiflorum J.J.S. & Guttiferae & III & II - IV \\
\hline 34314 & Ki bancet & Turpinia sphaerocarpa Hassk & Staphyleaceae & $\mathrm{V}$ & III - IV \\
\hline 34315 & Ki bulu & Girroniera subaequalis Planch. & Ulmaceae & IV - V & II - III \\
\hline
\end{tabular}

Sumber (Source): Oey Djoen Seng (1964)

Deskripsi ciri umum kayu diamati dari penampang lintang dolok kayu dan contoh kayu berbentuk papan yang sudah dihaluskan permukaannya. Ciri umum diamati menurut pola yang telah disusun oleh Martawijaya dan Kartasujana (1977). Kekerasan kayu ditetapkan dengan acuan yang ditetapkan oleh Den Berger (1949).

Karakteristik ciri anatomi kayu diamati pada sayatan mikrotom penampang lintang, radial dan tangensial yang diwarnai dengan safranin menurut petunjuk Sass (1961). Ciri anatomi diamati berdasarkan ciri-ciri yang telah dianjurkan oleh International Association of Wood Anatomist Committee (IAWA) (Wheeler et al., 1989).

Dimensi serat diukur pada preparat maserasi yang dibuat menurut petunjuk Schulze (Sass, 1961). Preparat maserasi dipersiapkan dengan memanaskan serpih kayu dalam campuran asam asetat dan hidrogen peroksida pada suhu $500-600^{\circ} \mathrm{C}$, sampai contoh uji berwarna pucat dan serat-serat kayu mudah dipisahkan. Waktu yang diperlukan bervariasi antara 12 - 24 jam bergantung pada kekerasan kayunya. Dimensi serat yang diukur dari preparat maserasi meliputi panjang, diameter dan diameter lumen serat.

Pengukuran ciri kuantitatif anatomi kayu dilakukan 30 kali dan dianalisa secara statistik deskriptif. Pengukuran ciri kuantitif anatomi meliputi diameter, panjang dan frekuensi pembuluh per $\mathrm{mm}^{2}$, serta tinggi dan frekuensi jari-jari per mm. Selain itu, dilakukan juga pengukuran terhadap noktah, baik noktah antar pembuluh dan jari-jari serta noktah antar serat.

Ciri kuantitatif anatomi kayu berupa diameter pembuluh dan panjang serat dinilai berdasarkan kriteria yang telah ditetapkan oleh Metcalfe dan Chalk (1983). Sedangkan, kualitas serat kayu dinilai berdasarkan kriteria kualitas serat yang disusun oleh Rachman dan Siagian (1976). 


\section{HASIL PENGAMATAN}

\section{A. Sterculia oblongata R.Br. - Sterculiaceae}

Sinonim : Sterculia spectabilis Miq., Sterculia kunstleri King., Sterculia forbesii Warb., Sterculia urceolate (Lemmens, 1995).

Nama setempat: Ki hantap

Ciri Umum

Warna : kayu teras berwarna kuning keabu-abuan, kurang jelas pemisahannya dengan kayu gubal yang berwarna lebih pucat. Corak : bergaris-garis. Tekstur : agak kasar. Arah serat : lurus sampai berpadu. Kilap: agak mengkilap. Kesan raba : kesat. Kekerasan : lunak.

\section{Ciri Anatomi}

Lingkaran tumbuh : jelas, ditandai oleh adanya parenkim pita marjinal. Pembuluh : baur, soliter dan berganda radial 2 - 4 sel, ukuran agak besar, diameter 270,98 \pm 51,46 $\mu \mathrm{m}$; frekuensi jarang, $3 \pm 0,4$ per $\mathrm{mm}^{2}$, panjang pembuluh 507,3 $\pm 6,6 \mu \mathrm{m}$, bidang perforasi sederhana. Noktah antar pembuluh berhalaman, bentuk bundar sampai lonjong bersusun berseling sampai berpasangan dan kadang memanjang; ukuran 8,9 $\pm 0,9 \mu \mathrm{m}$. Noktah antar pembuluh dan jari-jari sama dan seukuran dengan noktah antar pembuluh; tilosis dan endapan jarang dijumpai. Parenkim : difus, bentuk pita dan kadang dijumpai bersayap pendek. Selain itu, dijumpai juga parenkim difus berkelompok yang membentuk garis tangensial antar jari-jari. Jari-jari : 2 macam ukuran, jari-jari besar heteroseluler, agak lebar mencapai 14 sel, tinggi sampai 2.846,5 $\mu \mathrm{m}$, dengan rata-rata 1.687,3 $\pm 187,3 \mu \mathrm{m}$; jari-jari kecil 1 - 2 seriat, tinggi ratarata 1.015,9 $\pm 86,8 \mu \mathrm{m}$; frekuensi jari-jari besar dan kecil agak jarang 2,3 \pm 0,2 jari-jari per $\mathrm{mm}$. $\underline{\text { Serat }}$ : tanpa sekat; serat panjang, dengan rata-rata 2.065,6 $\pm 21,4 \mu \mathrm{m}$; diameter 36,6 $\pm 0,4 \mu \mathrm{m}$, tebal dinding $2,2 \pm 0,05 \mu \mathrm{m}$. Noktah antar serat berukuran 3,8 $\pm 0,2 \mu \mathrm{m}$. Inklusi material : sel kristal dijumpai pada jari-jari dan aksial parenkim. 


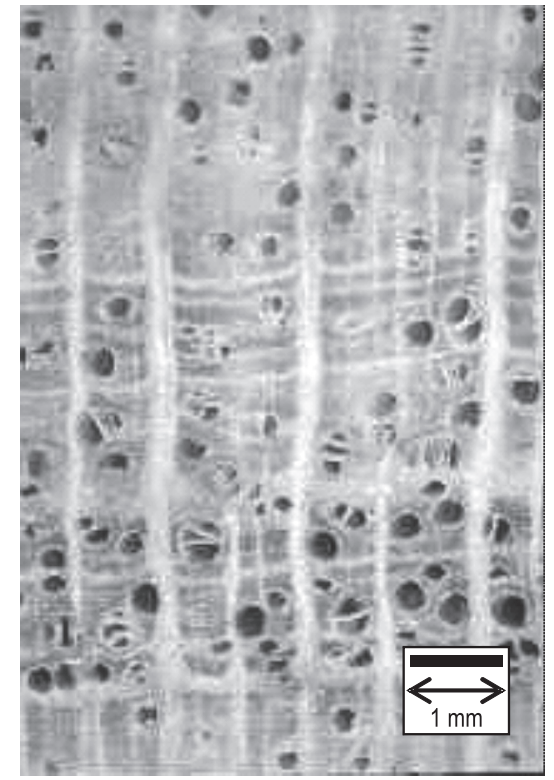

a

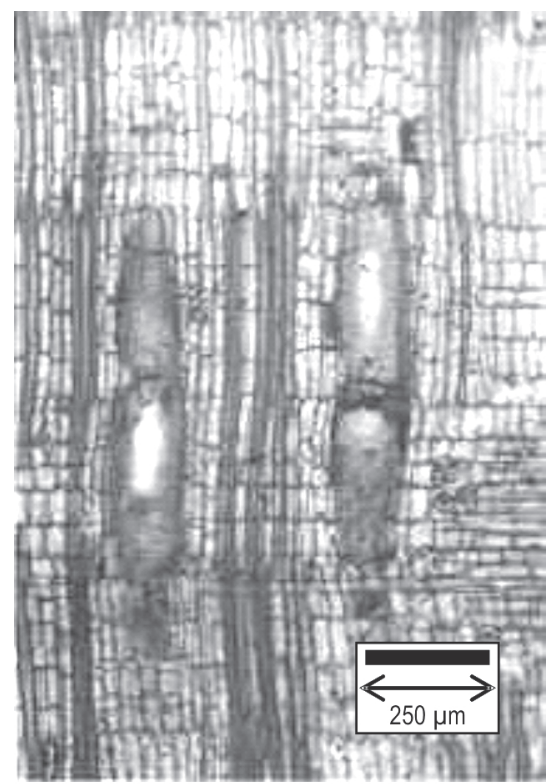

c

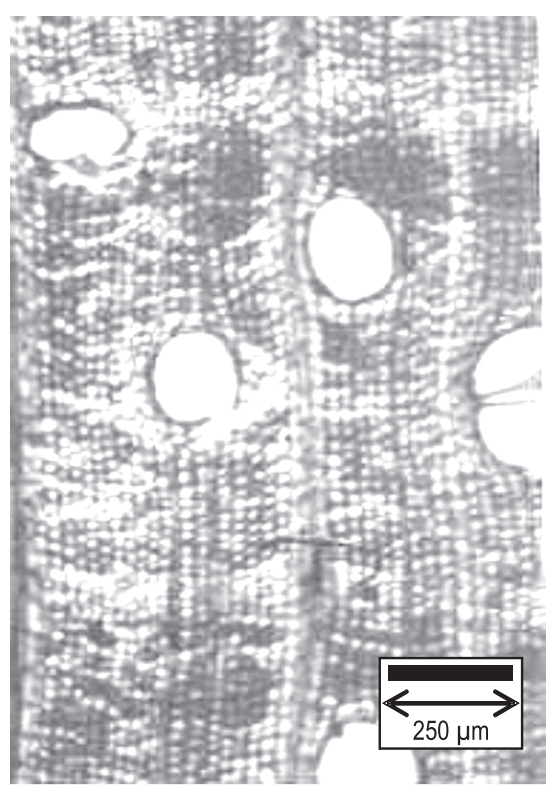

b



Gambar (Figure) 1. Sterculia oblongata R.Br.
a. penampang lintang (transversal surface)
b. penampang lintang (transversal surface)
c. penampang radial (radial surface)
d. penampang tangensial (tangential surface) 


\section{B. Ficus vasculosa Wall. ex Miq. - Moraceae}

Sinonim : Ficus championi Benth., Ficus renitens Miq., Ficus variabilis Miq.

(Boer dan Sosef, 1998b)

Nama setempat: Ki kuya

\section{Ciri Umum}

Warna : kayu teras kuning cerah tidak dipisahkan secara jelas dari kayu gubalnya. Corak : bergaris-garis. Tekstur : kasar. Arah serat : lurus sampai berpadu. Kilap : mengkilap. Kesan raba $:$ agak licin. Kekerasan: agak lunak.

\section{Ciri Anatomi}

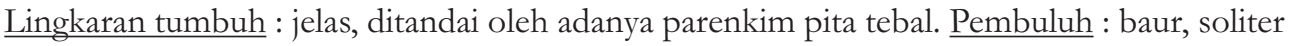
dan berganda radial 2 - 4 sel, diameter agak besar dengan rata-rata 220,1 $\pm 15 \mu \mathrm{m}$; frekuensi jarang, 3,07 \pm 0,36 per $\mathrm{mm}^{2}$; panjang pembuluh 421,9 \pm 4,7 $\mu \mathrm{m}$, bidang perforasi sederhana. Noktah antar pembuluh berhalaman, bentuk bundar sampai lonjong bersusun berseling, ukuran 7,5 $\pm 0,3 \mu \mathrm{m}$. Noktah antar pembuluh dan jari-jari sama dan seukuran dengan noktah antar pembuluh; tilosis banyak dan endapan putih kadang dijumpai. Parenkim : pita tebal sampai 16 sel, membentuk garis marjinal tidak terputus. Jari-jari : heteroseluler, dengan tinggi mencapai 1.147,3 $\mu \mathrm{m}$, dengan rata-rata 794,2 $\pm 76,3 \mu \mathrm{m}$; frekuensi $4 \pm 0,3$ jari-jari per $\mathrm{mm}$. Serat: tanpa sekat; dengan panjang $1.535 \pm 10 \mu \mathrm{m}$, diameter $30,3 \pm 0,4 \mu \mathrm{m}$, tebal dinding 2,24 $\pm 0,05$ mikron. Saluran interseluler: tidak dijumpai. Inklusi material: tidak dijumpai. 


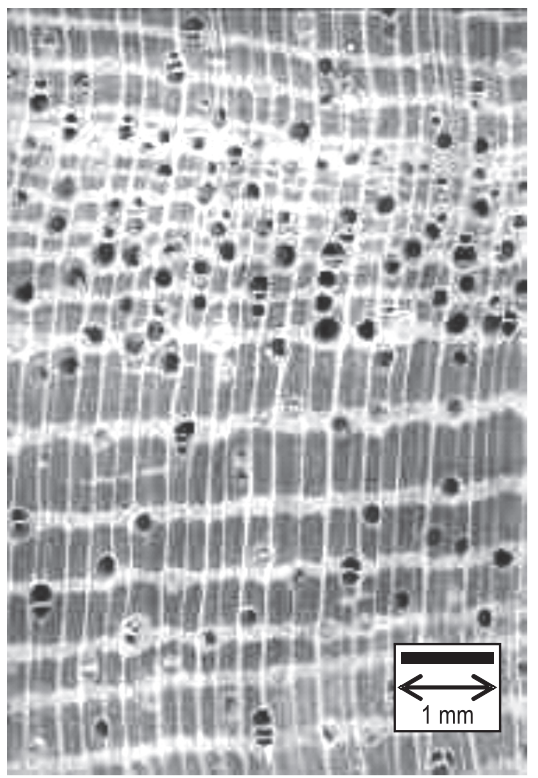

a

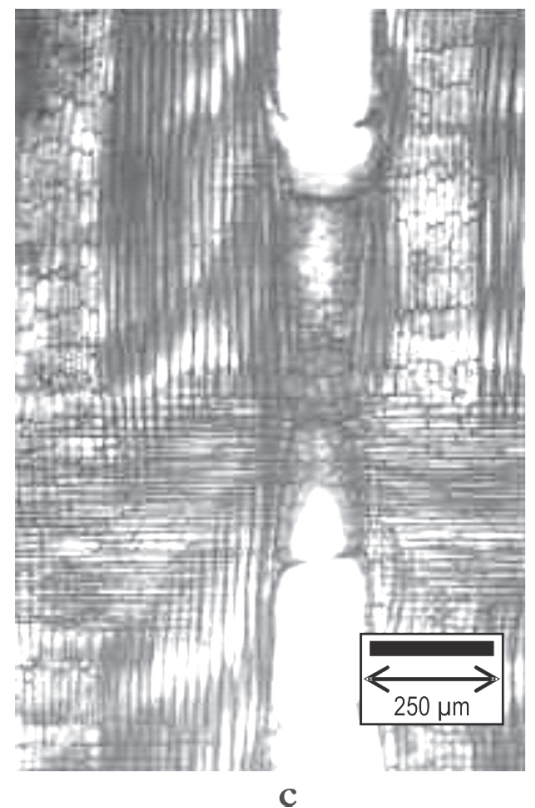

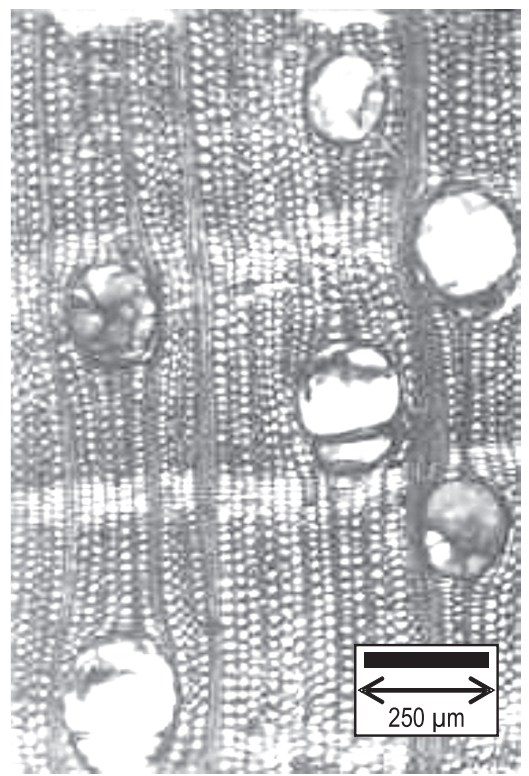

b

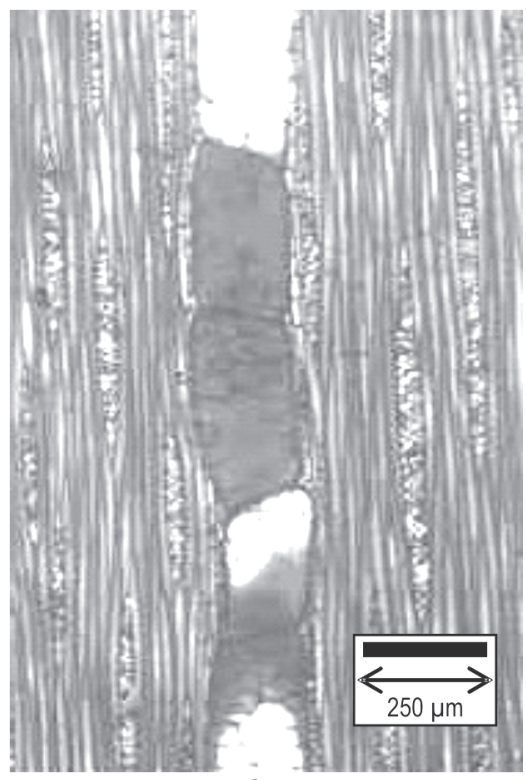

d

Gambar (Figure) 2. Ficus vasculosa Wall. ex Miq.

a. penampang lintang (transversal surface)

b. penampang lintang (transversal surface)

c. penampang radial (radial surface)

d. penampang tangensial (tangential surface) 


\section{Calophyllum grandiflorum J.J.S. -Guttiferae}

Nama setempat: Kilubang

\section{Ciri Umum}

Warna : kayu teras merah kecoklatan, dipisahkan secara jelas dengan kayu gubal yang berwarna coklat kekuningan agak merah jambu. Corak : bergaris-garis yang ditimbulkan oleh parenkim pita. Tekstur : agak kasar. Arah serat : berpadu. Kilap : mengkilap. Kesan raba : permukaan tangensial licin. Kekerasan: agak keras.

\section{Ciri Anatomi}

Lingkaran tumbuh : jelas, ditandai oleh adanya parenkim pita. Pembuluh : sebagian besar soliter, bersusun berkelompok radial atau diagonal; diameter agak besar dengan rata-rata $205,9 \pm 16,8 \mu \mathrm{m}$; frekuensi agak banyak $6,9 \pm 0,5$ per $\mathrm{mm}^{2}$; panjang pembuluh $811,9 \pm 24,4$ $\mu \mathrm{m}$, bidang perforasi sederhana. Noktah antara pembuluh dan jari-jari berhalaman, bentuk bundar sampai lonjong, bersusun berseling, ukuran kecil 7,8 $\pm 0,4 \mu \mathrm{m}$. Parenkim : pita memanjang kadang terputus, dengan ketebalan 4 - 8 sel. Jari-jari : heteroseluler, hampir seluruhnya uniseriat; tinggi sampai $801 \mu \mathrm{m}$, dengan rata-rata $500+69 \mu \mathrm{m}$; frekuensi agak banyak $8,9 \pm 0,3$ jari-jari per $m m$.

Serat : tanpa sekat; panjang 1.535,5 $\pm 10,6 \mu \mathrm{m}$, diameter 30,3 $\pm 0,4 \mu \mathrm{m}$, tebal dinding 2,2 \pm $0,05 \mu \mathrm{m}$ dengan noktah antar serat sederhana 5,6 0,2 $\mu \mathrm{m}$. Saluran interseluler: tidak dijumpai. Inklusi material : sel kristal dijumpai dalam jari-jari dan aksial parenkim. Endapan warna coklat kemerahan dijumpai pada jari-jari. 


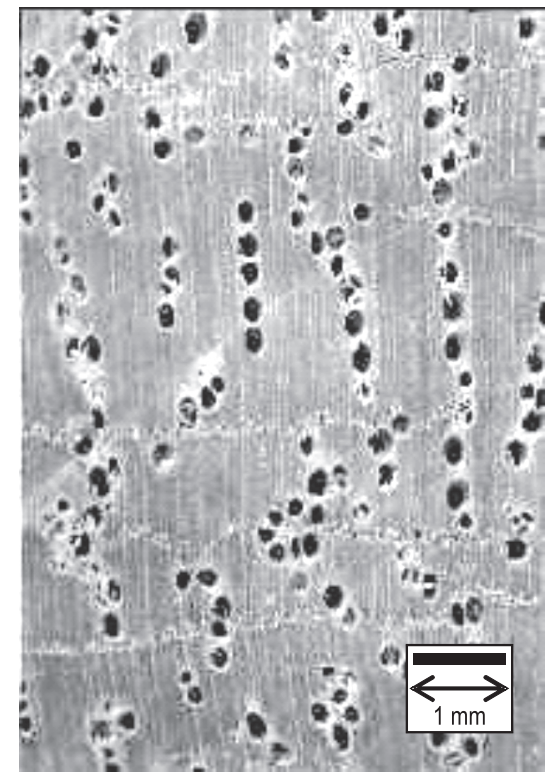

a

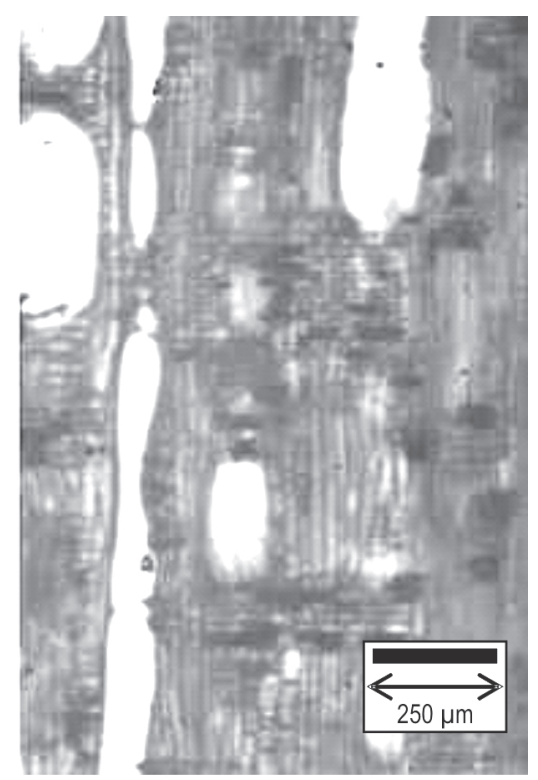

C

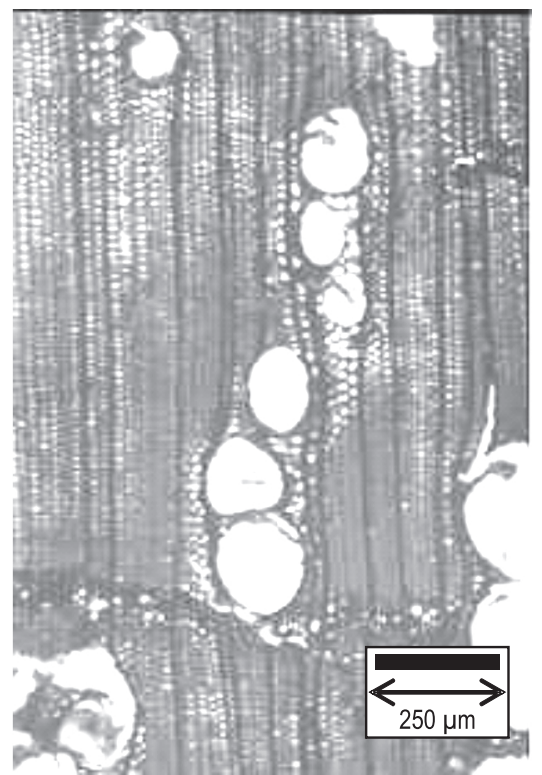

b

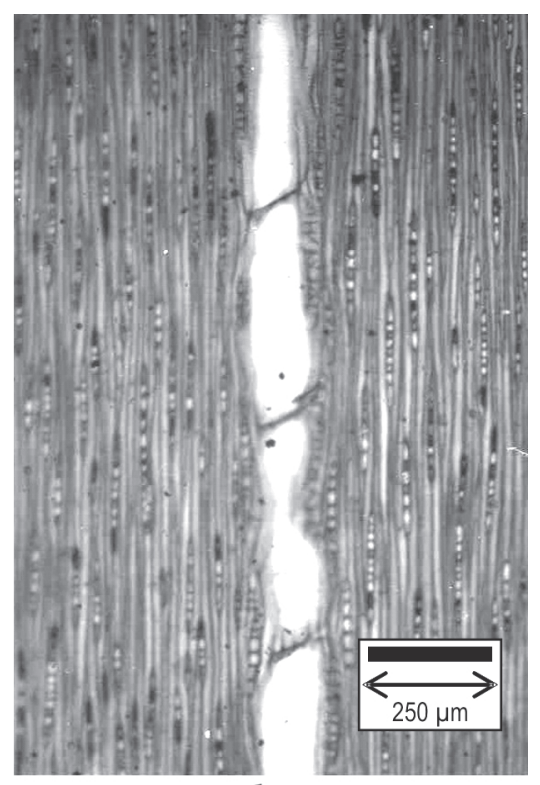

d

Gambar (Figure) 3. Calopbyllum grandiflorum J.J.S.
a. penampang lintang (transversal surface)
b. penampang lintang (transversal surface)
c. penampang radial (radial surface)
d. penampang tangensial (tangential surface) 


\section{Turpinia sphaerocarpa Hassk. - Staphyleaceae}

Sinonim : Turpinia latifolis Wallich ex Ridley, Turpinia laxiflora Ridley, Turpinia pomifera (Roxb.)

DC., Turpinia sambucifolia Elmer (Dasuki, 1998)

Nama setempat: Ki bancet

Ciri umum

Warna : kayu teras kekuningan, kurang jelas perbedaannya dengan kayu gubalnya yang lebih pucat. Corak : polos. Tekstur : agak halus. Arah serat : lurus. Kilap : mengkilap. Kesan raba : licin. Kekerasan: agak lunak.

Ciri Anatomi

Lingkaran tumbuh : kurang jelas, kadang ditandai oleh adanya lapisan gelap yang tidak berpembuluh. Pembuluh : baur, soliter, kadang dijumpai berganda radial dan berpasangan miring/tangensial, diameter sedang ukuran 122,2 \pm 6,9 $\mu \mathrm{m}$; frekuensi agak banyak 15,3 \pm 0,6 per $\mathrm{mm}^{2}$; panjang pembuluh 1.730,5 $\pm 38,6 \mu \mathrm{m}$, bidang perforasi bentuk tangga. Noktah antara pembuluh dan jari-jari sederhana, bentuk bundar sampai memanjang bersusun seperti tangga, ukuran 9,9 $\pm 0,5 \mu \mathrm{m}$; tilosis dan endapan tidak dijumpai. Parenkim : difus dan selubung, kadang dijumpai berbentuk sayap. Jari-jari : 2 macam ukuran, jari-jari besar heteroseluler biseriat 3 - 6 sel, tinggi sampai $2.219 \mu \mathrm{m}$, dengan rata-rata $1.447,9 \pm 121 \mu \mathrm{m}$, jarijari kecil 1 - 2 seriat, tinggi rata-rata 984,3 $\pm 38,2 \mu \mathrm{m}$; frekuensi jari-jari besar dan kecil agak banyak $8,7 \pm 0,4$ jari-jari per $m m$.

$\underline{\text { Serat: }}$ tanpa sekat; serat sangat panjang dengan ukuran 3.074,5 $\pm 34,2 \mu \mathrm{m}$, diameter 47,1 \pm 0,6 $\mu \mathrm{m}$, tebal dinding 5,4 \pm 6,6 $\mu \mathrm{m}$, noktah antar serat sederhana dengan ukuran 11,8 $\pm 0,6 \mu \mathrm{m}$. Saluran interseluler: tidak dijumpai. Inklusi mineral : tidak dijumpai. 


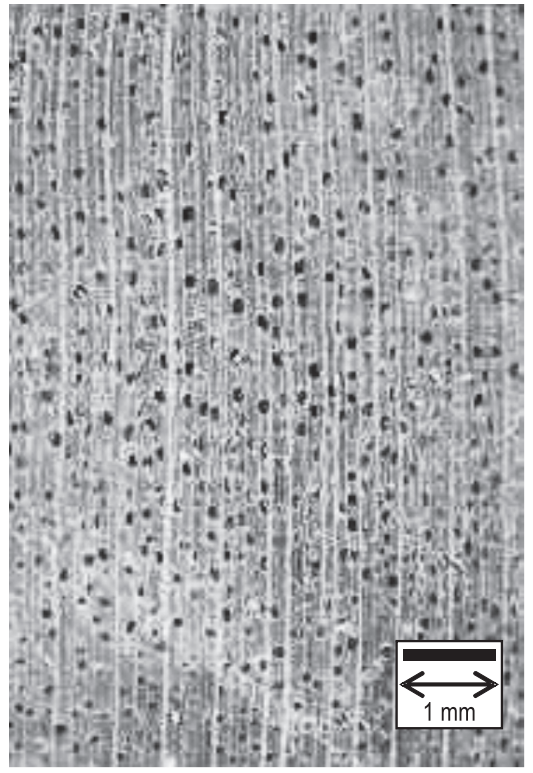

a

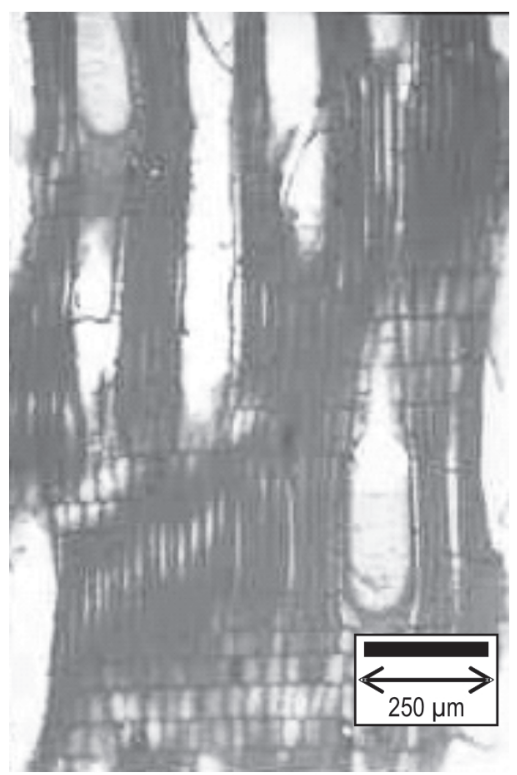

C



b

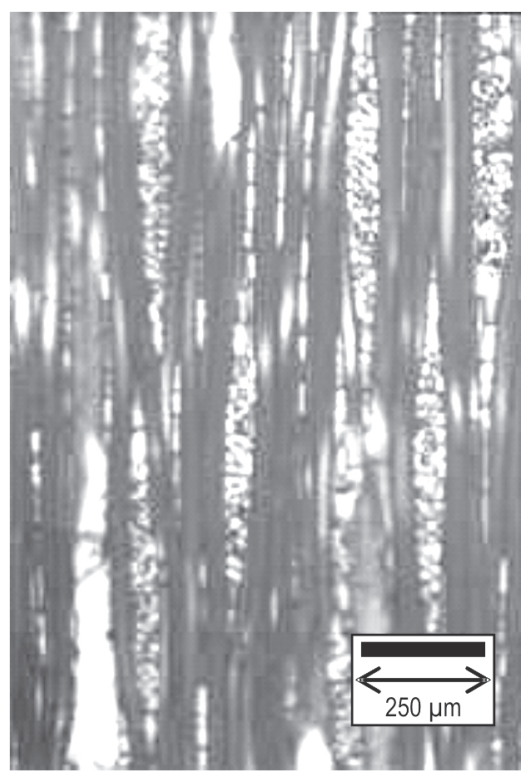

d

Gambar (Figure) 4. Turpinia sphaerocarpa Hassk.

a. penampang lintang (transversal surface)

b. penampang lintang (transversal surface)

c. penampang radial (radial surface)

d. penampang tangensial (tangential surface) 


\section{E. Gironniera subaequalis Planch. - Ulmaceae}

Sinonim : Gironniera amboinensis Luterb., Gironniera chinensis Benth., Gironniera sumatrana Gand. (Boer dan Sosef, 1998b)

Nama setempat: Kibulu

Ciri Umum

Warna : kayu teras berwarna kuning keputihan kurang jelas perbedaannya dengan kayu gubalnya. Corak : polos. Tekstur: halus. Arah serat : lurus. Kilap: mengkilap. Kesan raba: licin.

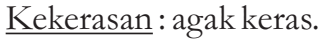

Ciri Anatomi

Lingkaran tumbuh : jelas, ditandai oleh adanya parenkim pita tipis dan perbedaan ketebalan dinding sel. Pembuluh : baur, soliter dan berganda radial 2 - 3 sel, diameter agak besar ukuran $217,3 \pm 14,8 \mu \mathrm{m}$; frekuensi agak jarang $6 \pm 0,4$ per $\mathrm{mm}^{2}$; bidang perforasi sederhana. Panjang pembuluh 909,4 $\pm 33,2 \mu \mathrm{m}$. Noktah antar pembuluh berhalaman, bersusun berseling, ukuran 13,3 \pm 0,6 $\mu \mathrm{m}$. Noktah antara pembuluh dan jari-jari sederhana dan lebih besar dari noktah antar pembuluh; tilosis dan endapan kadang dijumpai. Parenkim : bentuk pita tipis dan selubung. Jari-jari : 2 ukuran, jari-jari besar heteroseluler, biseriate 4 - 8 sel; tinggi mencapai $2.324 \mu \mathrm{m}$, dengan rata-rata 1.582,4 $\pm 157,5 \mu \mathrm{m}$. Jari-jari kecil 1 - 2 seriat, tinggi rata-rata 687,1 $\pm 22,4 \mu \mathrm{m}$; frekuensi jari-jari besar dan kecil sedang 4,2 \pm 0,3 jari-jari per $\mathrm{mm}$.

Serat: tanpa sekat; serat agak panjang dengan ukuran $2.186,7 \pm 21,8 \mu \mathrm{m}$, diameter 45,5 \pm 0,6 $\mu \mathrm{m}$, tebal dinding $3,5 \pm 0,07 \mu \mathrm{m}$. Noktah antar serat sederhana $4 \pm 0,2 \mu \mathrm{m}$.

Saluran interseluler: tidak dijumpai. Inklusi material : tidak dijumpai. 


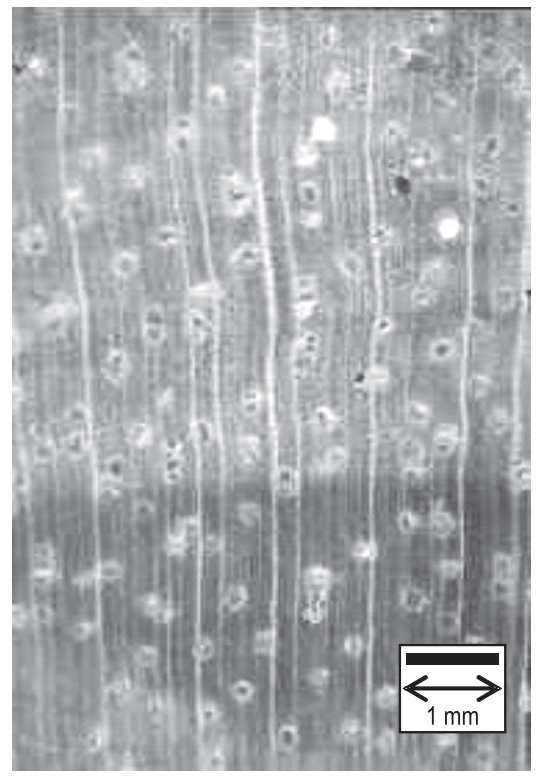

a

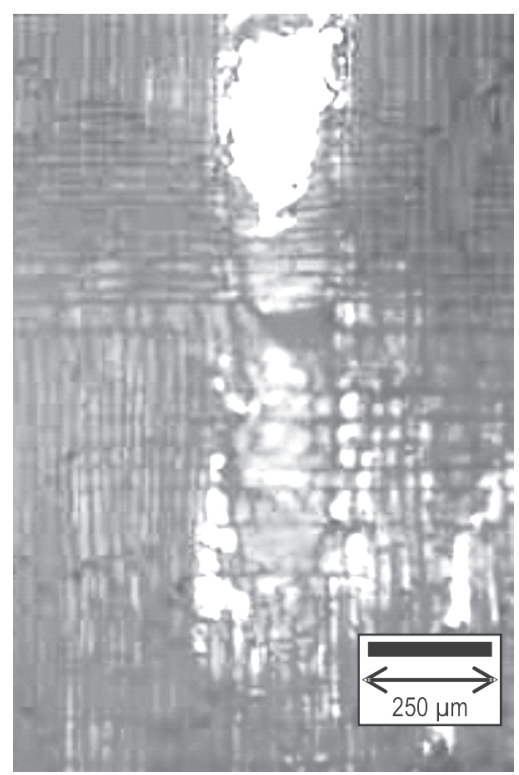

c



b



d

Gambar (Figure) 5. Gironniera subaequalis Planch.
a. penampang lintang (transversal surface)
b. penampang lintang (transversal surface)
c. penampang radial (radial surface)
d. penampang tangensial (tangential surface) 


\section{PEMBAHASAN}

\section{A. Identifikasi}

Ciri umum dan ciri anatomi lima jenis kayu kurang dikenal dari Desa Lengkong, Sukabumi sudah dipertelakan dalam bagian III. Foto penampang lintang, radial dan tangensial disajikan dalam Gambar 1 sampai 5. Seluruh kayu yang diamati berwarna kuning cerah sampai kuning pucat, kecuali ki lubang (Calophyllum grandiflorum) yang berwarna coklat kemerahan. Pada kayu ki lubang perbedaan antara kayu teras dan gubal terlihat jelas, sedangkan pada kayu lain kurang jelas.

Lingkaran tumbuh jelas terlihat pada seluruh kayu yang diamati, kecuali pada kayu ki bancet (Turpinia sphaerocarpa). Lingkaran tumbuh kayu ki hantap (Sterculia oblongata), ki kuya (Ficus vasculosa), ki lubang dan ki bulu (Gironniera subaequalis) dibentuk oleh adanya parenkim pita marjinal. Pada kayu ki bulu, selain parenkim pita juga terdapat bagian yang tidak mempunyai pembuluh, sehingga tampak seperti garis-garis gelap sebagai penanda lingkaran tumbuhnya.

Pembuluh seluruhnya tersebar membaur, kecuali pada kayu ki lubang pembuluhnya bersusun dalam kelompok radial atau diagonal miring. Diameter tangensial pembuluh pada umumnya berukuran agak besar sampai sedang, kecuali pada kayu ki bancet agak kecil dengan rata-rata $122,2 \pm 6,9 \mu \mathrm{m}$.

Parenkim pita dijumpai pada keempat jenis kayu yang dipelajari yaitu ki hantap, ki kuya, ki lubang dan ki bulu, sedangkan parenkim kayu ki bancet difus dan selubung jarang. Parenkim pita pada kayu ki kuya sangat tebal mencapai 16 sel, menimbulkan corak bergaris pada papan kayu ki kuya.

Jari-jari kayu yang diamati bervariasi, tiga jenis kayu; ki hantap, ki bancet dan ki bulu mempunyai dua ukuran, sedangkan kayu ki kuya dan ki lubang hanya mempunyai satu ukuran jari-jari. Jari-jari ki kuya dan ki lubang serta jari-jari besar pada ketiga jenis kayu lainnya heteroseluler biseriat dengan tebal 3 - 12 sel, sedangkan jari-jari ukuran kecil 1 - 2 seriat.

Sel kristal hanya dijumpai pada kayu ki hantap dan ki lubang. Sel kristal pada kedua jenis kayu dijumpai pada sel parenkim aksial dan jari-jari. Endapan warna putih dijumpai pada kayu ki kuya, sedangkan endapan warna coklat kemerahan dijumpai pada kayu ki lubang.

\section{B. Kualitas Serat}

Hasil pengukuran dan perhitungan dimensi serat disajikan dalam Tabel 2.

Berdasarkan data pengukuran dimensi serat pada Tabel 2, kayu ki bancet memiliki ratarata serat paling panjang. Menurut klasifikasi Metcalfe dan Chalk (1983), serat kayu ki bancet termasuk dalam kelas sangat panjang. Kayu ki hantap dan ki bulu termasuk dalam serat agak panjang dengan kisaran 1.600 - $2.200 \mu \mathrm{m}$. Dua jenis kayu lainnya, ki kuya dan ki lubang termasuk dalam kelas sedang.

Hasil perhitungan nilai turunan dimensi serat, disajikan dalam Tabel 3 
Tabel 2. Rata-rata dimensi serat 5 jenis kayu Table 2. The average fiber dimension of 5 wood species

\begin{tabular}{|l|l|c|c|c|c|}
\hline $\begin{array}{c}\text { Nama } \\
\text { Lokal } \\
\begin{array}{c}\text { Local } \\
\text { name })\end{array}\end{array}$ & $\begin{array}{c}\text { Jenis kayu } \\
\text { (Wood species) }\end{array}$ & $\begin{array}{c}\text { Panjang } \\
(\text { Length }) \\
(\mathrm{L})\end{array}$ & $\begin{array}{c}\text { Diameter } \\
(\mathrm{d})\end{array}$ & $\begin{array}{c}\text { Lumen } \\
(\mathrm{e})\end{array}$ & $\begin{array}{c}\text { Tebal dinding } \\
(\text { Wall thickness }) \\
(\mathrm{w})\end{array}$ \\
\cline { 3 - 6 } Ki hantap & Sterculia oblongata R.Br. & $2.065 \pm 70$ & $36,6 \pm 0,7$ & $32,2 \pm 0,7$ & $2,2 \pm 0,07$ \\
\hline Ki kuya & Ficus vasculosa Wall.ex Miq. & $1.525 \pm 105$ & $37,0 \pm 1,3$ & $32,8 \pm 1,2$ & $2,1 \pm 0,06$ \\
\hline Ki lubang & Calophyllum grandiflorum JJS. & $1.535 \pm 79$ & $30,3 \pm 0,9$ & $25,8 \pm 0,9$ & $2,2 \pm 0,06$ \\
\hline Ki bancet & Turpinia sphaerocarpa Hassk. & $3.156 \pm 125$ & $48,3 \pm 1,4$ & $41,5 \pm 1,3$ & $3,4 \pm 0,08$ \\
\hline Ki bulu & Girroniera subaequalis Planch. & $2.503 \pm 54$ & $47,1 \pm 1,1$ & $40,1 \pm 1,2$ & $3,5 \pm 0,11$ \\
\hline
\end{tabular}

Tabel 3. Nilai turunan dimensi dan kualitas serat Table 3. Derivation value of fiber dimension and its quality

\begin{tabular}{|l|l|c|c|c|c|c|c|}
\hline $\begin{array}{l}\text { Nama lokal } \\
\text { (Local name) }\end{array}$ & \multicolumn{1}{|c|}{ Jenis kayu } & A & B & C & D & E & $\begin{array}{c}\text { Kualitas serat } \\
\text { (Fiber quality) }\end{array}$ \\
\hline Ki hantap & Sterculia oblongata & 56,50 & 22,58 & 0,88 & 0,14 & 0,06 & I \\
\hline Ki kuya & Ficus vasculosa & 41,52 & 21,63 & 0,89 & 0,13 & 0,06 & I \\
\hline Ki lubang & Calophyllum grandiflorum & 50,96 & 27,47 & 0,85 & 0,17 & 0,07 & I \\
\hline Ki bancet & Turpinia sphaerocarpa & 65,35 & 26,43 & 0,86 & 0,17 & 0,07 & I \\
\hline Ki bulu & Girroniera subaequalis & 52,72 & 27,63 & 0,85 & 0,18 & 0,07 & I \\
\hline
\end{tabular}

Keterangan (Remarks) :

A = Daya tenun (Felting power), $\mathrm{L} / \mathrm{d}$

$\mathrm{B}=$ Perbandingan Muhlsteph (Mublsteph ratio), $\left[\left(\mathrm{d}^{2}-\mathrm{e}^{2}\right) / \mathrm{d}^{2}\right] \times 100 \%$

$\mathrm{C}=$ Perbandingan fleksibilitas (Flexibility ratio), e / d

$\mathrm{D}=$ Perbandingan Runkel (Runkel ratio), $2 \mathrm{w} / \mathrm{e}$

$\mathrm{E}=$ Koefisien kekakuan (Coeficient of rigidity), w / d

Untuk notasi-notasi L, d, e dan w, lihat Tabel 2 (For the code: $L$, d, e and w, please refer to Table 2)

Berdasarkan perhitungan Tabel 3. dapat diketahui bahwa kualitas serat kelima jenis kayu dalam hubungannya sebagai bahan kertas termasuk dalam kelas sangat bagus (kelas kualitas I). Kelas kualitas I menurut Rachman dan Siagian (1976) adalah jenis kayu agak ringan sampai ringan dengan dinding serat sangat tipis dengan lumen relatif lebar. Dalam pembuatan pulp serat akan menggepeng seluruhnya dengan ikatan antar serat dan tenunannya sangat kuat. Lembaran pulp yang dihasilkan mempunyai keteguhan sobek, pecah dan tarik yang tinggi. 


\section{Kemungkinan Penggunaan}

Kelima jenis kayu yang dipelajari memiliki kekerasan dari lunak sampai agak keras. Kayu ki lubang yang agak keras dikenal dalam kelompok kayu perdagangan bintangur. Dalam kelompok kayu bintangur yang utamanya jenis Calophyllum inophyllum, kayu ini telah digunakan sebagai konstruksi ringan, papan lantai, moulding, papan geladak, papan panel, papan sambung, mebel, venir dan kayu lapois, pallet, konstruksi kapal dan alat musik (Lim, 1994).

Kayu ki bulu termasuk kayu agak keras. Ki bulu dapat digunakan sebagai bahan baku mebel, terutama produk mebel yang membutuhkan warna cerah. Kayu ini sebaiknya digunakan dalam ruangan seperti mebel dan papan lantai (Boer dan Sosef, 1998a). Penggunaan di luar ruangan tidak dianjurkan karena kayu ini rentan terhadap serangan rayap dan jamur serta kerusakan fisik akibat perubahan cuaca.

Kayu ki bancet dan ki kuya termasuk dalam kategori agak lunak. Kedua jenis kayu dapat digunakan sebagai bahan baku mebel, perlengkapan rumah tangga, konstruksi sementara, molding, peti pembungkus, dan tirai/kerai kayu, tangkai dan sendok es krim (Dasuki, 1998; Boer dan Sosef, 1998b). Kayu ki kuya memiliki parenkim pita yang tebal, sehingga memberikan corak bergaris-garis putih. Penggunaannya sebagai molding dan tirai/kerai memberikan daya tarik tersendiri.

Kayu ki hantap termasuk dalam kategori kayu ringan, yang dapat digunakan sebagai bahan konstruksi ringan atau sementara, peti pembungkus dan tangkai sepatu (Lemmens, 1995).

Berdasarkan nilai turunannya, kualitas serat kelima jenis kayu termasuk dalam kelas I. Dalam pembuatan pulp, seratnya akan mudah menggepeng, sehingga ikatan antar serat dan tenunannya sangat kuat. Lembaran pulp yang dihasilkan akan mempunyai keteguhan sobek, pecah dan tarik yang tinggi.

\section{KESIMPULAN}

1. Kayu ki hantap (Sterculia oblongata R.Br.) berwarna kuning keabu-abuan, corak bergaris, dengan lingkaran tumbuh jelas oleh parenkim pita. Parenkim bentuk sayap, dan difus berkelompok, jari-jari 2 ukuran.

2. Kayu ki kuya (Ficus vasculosa Wall. ex Miq.) berwarna kuning cerah, lingkaran tumbuh jelas oleh parenkim pita. Parenkim pita tebal membentuk corak garis-garis putih pada produk kayunya.

3. Kayu ki lubang (Calophyllum grandiflorum J.J.S.) berwarna coklat kemerahan dan termasuk dalam kelompok kayu perdagangan bintangur. Pembuluh kayu ki lubang bersusun dalam kelompok radial atau diagonal dan parenkim pita memanjang yang kadang terputus.

4. Kayu ki bancet (Turpinia sphaerocarpa Hassk.) berwarna kekuningan, agak lunak. Lingkaran tumbuh kayu ki bancet kurang jelas, pembuluhnya agak banyak dan berukuran agak kecil, jari-jari 2 macam ukuran.

5. Kayu ki bulu (Gironniera subaequalis Planch.) berwarna kuning keputihan dan agak keras. 
Lingkaran tumbuhnya jelas oleh adanya parenkim pita tipis dan perbedaan ketebalan dinding selnya, jari-jari 2 ukuran.

6. Serat kelima jenis kayu termasuk dalam kelas kualitas I sebagai bahan baku pulp untuk kertas.

\section{Ucapan Terima Kasih}

Penulis mengucapkan terima kasih kepada Bapak Usep Sudarji atas bantuannya dalam pembuatan preparat sayatan dan Ibu Tutiana dalam pembuatan dan pengukuran dimensi serat.

\section{DAFTAR PUSTAKA}

Boer, E. dan M.S.M. Sosef. 1998a. General part of Ficus L. In Sosef, M.S.M., L.T. Hong and S. Prawirohatmodjo (Eds.). Plant Resources of South East Asia No.5(3). Timber trees: Lesser-known timbers. Backhuys Publisher, Leiden. p. 233-238.

.1998b. General part of Gironniera Gaudich. In Sosef, M.S.M., L.T. Hong and S.Prawirohatmodjo (Eds.). Plant Resources of South East Asia No.5(3). Timber trees: Lesser-known timbers. Backhuys Publisher, Leiden. p. 255-256.

Dasuki, U.A. 1998. General part, properties and wood anatomy of Turpinia Vent. In Sosef, M.S.M., L.T. Hong and S.Prawirohatmodjo (Eds.). Plant Resources of South East Asia No.5(3). Timber trees: Lesser-known timbers. Backhuys Publisher, Leiden. p. 570-571.

Den Berger, L.G. 1949. Determinatietabel voor houtsoorten van Malesie tot op Famile of geslacht. Balai Penjelidikan Kehutanan Bogor. Indonesia.

Laban, B.Y. 2005. Prospek produk industri hasil hutan Indonesia. Paper dalam Seminar Kesiapan Indonesia dalam implementassi ISPM \# 15: Solid Wood Packaging Material. Pusat Standardisasi dan Lingkungan, Sekjen Departemen Kehutanan. Jakarta, 27 April.

Lemmens, R.H.M.J. 1995. General part of Sterculia L. In Soerianegara I., and R.H.M.J. Lemmens (Eds.). Plant Resources of South East Asia 5(2). Timber trees: Minor Commercial Timbers. PROSEA Foundation. Bogor. p.423-435.

Lim, S.C. 1994. General part of Calophyllum L. In Soerianegara I., and R.H.M.J. Lemmens (Eds.). Plant Resources of South East Asia 5(1). Timber trees: Major Commercial Timbers. PROSEA Foundation, Bogor. p.114-132.

Martawijaya, A. dan I. Kartasudjana. 1977. Ciri umum, sifat dan kegunaan jenis-jenis kayu Indonesia. Publikasi Khusus No. 41, Lembaga Penelitian Hasil Hutan. Bogor.

Martawijaya, A., I. Kartasudjana, K. Kadir dan S.A. Prawira. 1981. Atlas Kayu Indonesia Jilid I. Pusat Penelitian dan Pengembangan Kehutanan. Bogor.

Metcalfe, C.R. dan I. Chalk. 1983. Anatomy of the Dicotyledons. $2^{\text {nd }}$ edition. Vol.II. Wood structure and conclusion of the general introduction. Oxford: Clarendon Press. 
JURNAL Penelitian Hasil Hutan Vol. 24 No. 3, Juni 2006: 201-218

Oey Djoen Seng. 1964. Berat jenis kayu Indonesia dan pengertian berat jenisnya untuk keperluan praktek. Pengumuman No.13, Lembaga Penelitian Hasil Hutan. Bogor.

Rachman, A.N. dan R.M.Siagian. 1976. Dimensi serat jenis kayu Indonesia. Laporan No.75. Lembaga Penelitian Hasil Hutan. Bogor.

Sass, J.E. 1961. Botanical microtechnique. The IOWA State University Press.

Wheeler, E.A., P. Baas and E.Gasson. 1989. IAWA list of microscopic features for hardwood identification. IAWA Bulletin. N.S. 10(3): 219-332.

Wargadalam, A. 2005. Strategi Departemen Perindustrian dalam penyelamatan industri kehutanan. Makalah pada Seminar Hasil Litbang Hasil Hutan, 30 November. Puslitbang Hasil Hutan. Bogor. 


\title{
EFEKTIVITAS PENULARAN BEBERAPA ISOLAT JAMUR PATOGEN SERANGGA Metarbizium anisopliae OLEH RAYAP PEKERJA Coptotermes curvignathus
}

\author{
(Effectiveness of Transmission of Some Isolates of Entomopathogenic \\ Fungus Metarhizium anisopliae by Subterranean Termite Workers, \\ Coptotermes curvignathus)
}

\author{
Oleh/By :
}

\author{
Neo Endra Lelana ${ }^{1)}$, Paimin Sukartana ${ }^{1)}$, Agus Ismanto ${ }^{1)}$ \& Rusti Rushelia ${ }^{2)}$
}

\begin{abstract}
Entomopathogenic fungus Metarhizium anisopliae is known as a pathogen of a wide range of insect species, including termite. This insect pathogen is transmitted by its spores. Six isolates of this fungus species have been collected from some locations in Java. Effectiveness of spores transmission of these isolates amongst workers caste of subterranean termite Coptotermes curvignathus was evaluated under laboratory trials. Some termite groups containing of infected and uninfected termite workers with fungus spores of these isolates, set up in culture vials filled with moistened sterile sand media, were incubated in a dark and humid at room temperature for 14 days for their contagious effects. Contagious effect was shown by much greater percent mortality of each termite group than number of previously infected termites. Isolates obtained from Research Institute for Estate Crop Biotechnology Bogor (BGR), Faculty of Agriculture, Gadjah Mada University Yogyakarta (UGM)p and Institute of Protection of Estate Crops Semarang (SMG) showed highly potential, causing of more than $80 \%$ mortality on 50\% concentration of infected termites. BGR isolate seemed to be the most effective isolate to be transmitted by termite workers into its colony.
\end{abstract}

Keywords : Entomopathogenous fungus, M. anisopliae, C. curvignathus, spore contagiousness, termite mortality

\begin{abstract}
ABSTRAK
Jamur patogen serangga Metarbizium anisopliae diketahui bersifat patogen terhadap banyak serangga termasuk rayap. Penularan terjadi melalui penyebaran spora. Efektivitas penularan oleh kasta rayap pekerja Coptotermes curvignathus yang telah terinfeksi spora jamur dari 6 isolat yang dikumpulkan dari berbagai lokasi di Jawa dievaluasi. Beberapa kelompok rayap yang terdiri dari campuran rayap pekerja yang terinfeksi spora dan yang sehat dimasukkan dalam botol kultur berisi media pasir steril yang lembab, diinkubasi dalam ruang gelap dan lembab pada suhu kamar selama 14 hari. Hasil
\end{abstract}

\footnotetext{
1) Peneliti pada Pusat Penelitian dan Pengembangan Hasil Hutan, Bogor

2) Teknisi pada Pusat Penelitian dan Pengembangan Hasil Hutan, Bogor
} 
penelitian menunjukkan bahwa persentase mortalitas rayap cenderung meningkat setelah inkubasi dibandingkan dengan sebelum inkubasi. Isolat dari Balai Penelitian Bioteknologi Perkebunan Bogor (BGR), Fakultas Pertanian Universitas Gajah Mada Yogyakarta (UGM)p dan Balai Proteksi Tanaman Perkebunan Semarang (SMG) menunjukkan efektivitas penularan yang tinggi, menyebabkan mortalitas rayap lebih dari $80 \%$ pada perlakuan rayap terinfeksi dengan konsentrasi $50 \%$. Isolat dari Bogor tampaknya paling efektif untuk ditularkan oleh rayap pekerja ke dalam koloninya.

Kata kunci: Jamur patogen serangga, M. anisopliae, C. curvignathus, penularan spora, mortalitas rayap

\section{PENDAHULUAN}

Jamur patogen serangga Metarbizium anisopliae (Metschnikoff) Sorokin diketahui bersifat patogen terhadap sekitar 200 spesies serangga (Cloyd, 2002), sehingga memungkinkan untuk digunakan sebagai agen pengendali hama serangga termasuk rayap. Pada skala laboratorium, M. anisopliae efektif terhadap beberapa jenis rayap (Hanel, 1982). Jamur ini bahkan dapat mematikan koloni rayap tanah Coptotermes acinnaciformis dengan menaburkan 10 gr serbuk spora ( $=3 \times 10^{11}$ spora) di tengah koloninya (Milner et al., 1998).

Rayap tanah cenderung mempertahankan kelembaban yang tinggi di sarangnya. Kondisi ini sangat kondusif untuk pertumbuhan jamur entomopatogen yang dapat menginfeksi rayap. Milner et al. (1997) menyatakan bahwa iklim mikro yang cukup lembab di sekeliling koloni rayap tanah mendukung terjadinya infeksi jamur patogen terhadap rayap tersebut.

Jamur entomopatogen berpotensi dikembangkan untuk metode pengumpanan, karena beraksi secara perlahan, bisa memperbanyak diri sendiri dan aman terhadap serangga non target (Grace and Zoberi, 1992). Efektivitas penularan spora jamur pada koloni rayap merupakan faktor yang menentukan dalam keberhasilan metode pengumpanan. Adanya interaksi fisik antar individu dalam koloni rayap, misalnya kegiatan saling menyuapi (trophallaxis) dan bersentuhan (grooming), memungkinkan terjadinya penularan spora jamur dari rayap yang terinfeksi dengan rayap yang sehat dalam koloni tersebut (Kramm et al., 1982).

Penelitian ini bertujuan untuk mengetahui efektivitas penularan spora jamur entomopatogen $M$. anisopliae di antara kasta pekerja rayap tanah C. curvignathus sebagai dasar untuk pengembangan jamur tersebut sebagai agen pengendali rayap yang ramah lingkungan.

\section{BAHAN DAN METODE}

\section{A. Isolat Metarhizium anisopliae}

Penelitian ini menggunakan 6 isolat $M$. anisopliae. Isolat BGR dikoleksi dari Balai Penelitian Bioteknologi Tanaman Perkebunan Bogor, isolat BDG dari Balai Proteksi Tanaman Perkebunan Bandung (BPTP), isolat SMG dari BPTP Semarang, isolat JBG dari BPTP Jombang, dan isolat UGMd dan UGMp dari Jurusan Hama dan Penyakit Tanaman, Fakultas Pertanian Universitas Gadjah Mada. Isolat-isolat tersebut di atas pada umumnya digunakan untuk pengendalian hama perkebunan, terutama kelapa dan tebu. 
Isolat yang dikumpulkan, dipelihara dalam media potato dextrose agar (PDA) dan diinkubasikan pada suhu kamar. Spora dari biakan jamur yang telah berumur 14 hari dipanen secara hati-hati dengan jarum ose. Biakan yang berumur 14 hari ini dipilih untuk memastikan bahwa semua isolat sudah cukup matang (Jones, et al., 1996). Spora kemudian dimasukkan ke dalam tabung reaksi steril dan disimpan dalam inkubator pada suhu $30^{\circ} \mathrm{C}$ selama 30 menit untuk meminimalkan penggumpalan spora.

\section{B. Rayap}

Rayap yang digunakan adalah Coptotermes curvignathus (Isoptera: Rhinotermitidae) yang dikoleksi dengan teknik pengumpanan dari sebuah koloni di Kebun Percobaan Hasil Hutan di Cikampek. Rayap dipelihara selama beberapa minggu di laboratorium supaya beradaptasi dengan lingkungan yang baru. Jenis rayap ini dipilih karena termasuk hama bangunan yang ganas.

\section{Uji Penularan}

Uji penularan dilakukan dengan memasukkan rayap yang terinfeksi spora jamur ke tempat yang sudah berisi rayap sehat. Menginfeksi rayap dilakukan dengan memasukkan rayap ke dalam tabung reaksi yang berisi spora. Tabung reaksi kemudian diguling-gulingkan perlahan-lahan dan rayap dibiarkan berjalan keluar dengan sendirinya agar spora tidak banyak yang hilang. Rayap yang sudah terinfeksi dimasukkan ke dalam botol kultur ukuran $100 \mathrm{ml}$ yang telah diisi $10 \mathrm{~g}$ pasir ayak steril dengan kadar air sekitar 20\% (berat/berat) dan rayap sehat. Perbandingan antara rayap terinfeksi terhadap jumlah keseluruhan rayap pada tiap-tiap perlakuan adalah 10, 20, 50 dan 100\% (Tabel 1). Tiap perlakuan menggunakan rayap pekerja sebanyak 50 ekor dengan ulangan sebanyak lima kali. Sebagai pakan digunakan kayu tusam (Pinus merkusii) berukuran 1 x 0,5 x 0,5 cm. Percobaan diinkubasi di ruang gelap pada suhu kamar selama 14 hari.

Tabel 1. Perbandingan jumlah rayap yang terinfeksi dengan jumlah rayap seluruhnya Table 1. Ratio of infected termite workers to total termite group

\begin{tabular}{|c|c|c|c|}
\hline \multirow{2}{*}{$\begin{array}{c}\text { Persentase rayap terinfeksi } \\
\text { (Percent of infected termites), } \%\end{array}$} & \multicolumn{3}{|c|}{$\begin{array}{c}\text { Jumlah rayap pekerja } \\
\text { (Number of termite workers) }\end{array}$} \\
\cline { 2 - 4 } & $\begin{array}{c}\text { Terinfeksi } \\
\text { (Infected) }\end{array}$ & $\begin{array}{c}\text { Sehat } \\
\text { (Healthy) }\end{array}$ & $\begin{array}{c}\text { Total } \\
\text { (Total) }\end{array}$ \\
\hline Kontrol (Contro) & 0 & 50 & 50 \\
10 & 5 & 45 & 50 \\
20 & 10 & 40 & 50 \\
50 & 25 & 25 & 50 \\
100 & 50 & 0 & 50 \\
\hline
\end{tabular}


Mortalitas rayap dihitung setelah 14 hari inkubasi. Persentase mortalitas rayap ditransformasi ke dalam nilai arcsin $\sqrt{\text { persen }}$ dan kemudian dianalisis dengan ANOVA. Berdasarkan hasil ANOVA, dilakukan uji beda dengan metode Tuckey untuk mengetahui perbedaan antara perlakuan satu dengan yang lain (Steel and Torrie, 1980).

Jumlah spora jamur yang menempel pada kutikula rayap yang telah terinfeksi dihitung. Sebanyak 10 rayap pekerja yang telah terinfeksi spora jamur dimasukkan ke dalam tabung mikrosentrifus yang telah berisi $1 \mathrm{ml}$ larutan $0,05 \%$ Tween 80 . Suspensi spora dihomogenkan dengan vortex mixer selama 3 menit. Dari suspensi ini jumlah spora kemudian dihitung menggunakan alat Neubauer Haemacytometer di bawah mikroskop.

\section{HASIL DAN PEMBAHASAN}

Hasil penelitian menunjukkan bahwa spora jamur dapat ditularkan rayap kepada anggota lain dalam koloninya. Hal ini ditunjukkan dengan persentase mortalitas rayap setelah masa inkubasi selama 14 hari lebih besar daripada persentase rayap yang terinfeksi (Tabel 2). Hasil ini menegaskan hasil penelitian sebelumnya mengenai terjadinya penularan spora jamur M. anisopliae antar pekerja rayap tanah C. curvignathus (Sukartana et at., 2000).

Tabel 2. Rata-rata persentase mortalitas rayap setelah diinkubasi Table 2. Average mortality percentage of termites after incubated

\begin{tabular}{|c|c|c|c|c|c|}
\hline \multirow{3}{*}{$\begin{array}{l}\text { Isolat } \\
\text { (Isolate) }\end{array}$} & \multicolumn{5}{|c|}{$\begin{array}{l}\text { Persentase mortalitas } \\
\quad(\text { Percent mortality })^{1}\end{array}$} \\
\hline & \multicolumn{5}{|c|}{$\begin{array}{l}\text { Persentase rayap terinfeksi terhadap jumlah seluruhnya } \\
\text { (Percent infected) }\end{array}$} \\
\hline & $\begin{array}{l}\text { Kontrol } \\
\text { (Control) }\end{array}$ & $10 \%$ & $20 \%$ & $50 \%$ & $100 \%$ \\
\hline SMG & 3,2 & $18 \pm 1^{\mathrm{ab}}$ & $33 \pm 10^{b}$ & $89 \pm 7 b$ & 100 \\
\hline BGR & 3,2 & $24,5 \pm 2^{\mathrm{a}}$ & $63 \pm 12^{a}$ & $100 \pm 0^{a}$ & 100 \\
\hline $\mathrm{UGM}_{\mathrm{p}}$ & 3,2 & $14 \pm 1^{b}$ & $28,5 \pm 5^{b}$ & $95,5 \pm 5^{\mathrm{ab}}$ & 100 \\
\hline $\mathrm{UGM}_{\mathrm{d}}$ & 3,2 & $14 \pm 3^{b}$ & $33 \pm 7^{b}$ & $72,5 \pm 4^{b c}$ & 100 \\
\hline JBG & 3,2 & $7,5 \pm 3 c$ & $24 \pm 3^{b}$ & $61 \pm 5^{c}$ & 100 \\
\hline BDG & 3,2 & $8,5 \pm 2^{c}$ & $24,5 \pm 5^{b}$ & $66 \pm 6^{c}$ & 100 \\
\hline
\end{tabular}

Keterangan (Remarks) : ${ }^{1}=$ Angka-angka pada masing-masing lajur yang diikuti dengan huruf yang sama tidak berbeda nyata menurut analisis Tuckey, $\mathrm{P}<0,05$ (Numbers in each column followed by the same letter were not significantly different according to Tukey's $w$ Procedure, $P<0.05)$. 
Penularan spora dari rayap yang terinfeksi kepada rayap yang sehat disebabkan adanya interaksi antar individu, seperti tingkah laku rayap yang saling menyuapi (trophallaxis) dan saling bersentuhan (grooming) (Kramm et al., 1982). Sebagai serangga sosial, tingkah laku individu rayap memang selalu berhubungan dengan anggota yang lain dalam koloninya.

Jamur patogen ini menginfeksi rayap dengan melakukan penetrasi langsung ke dalam tubuh rayap dan kemudian berkecambah menutupi seluruh tubuh rayap (Gillespie and Moorhouse, 1988). Jenis jamur ini mampu menembus kutikula rayap karena memproduksi enzim kitinase dan protease (Huber, 1958 cit Gabriel, 1968) yang dapat melisis kitin pada kutikula rayap. Jamur akan tumbuh dan berkembang pada rayap yang terinfeksi, dan selanjutnya akan terjadi sporulasi (Gambar 1).
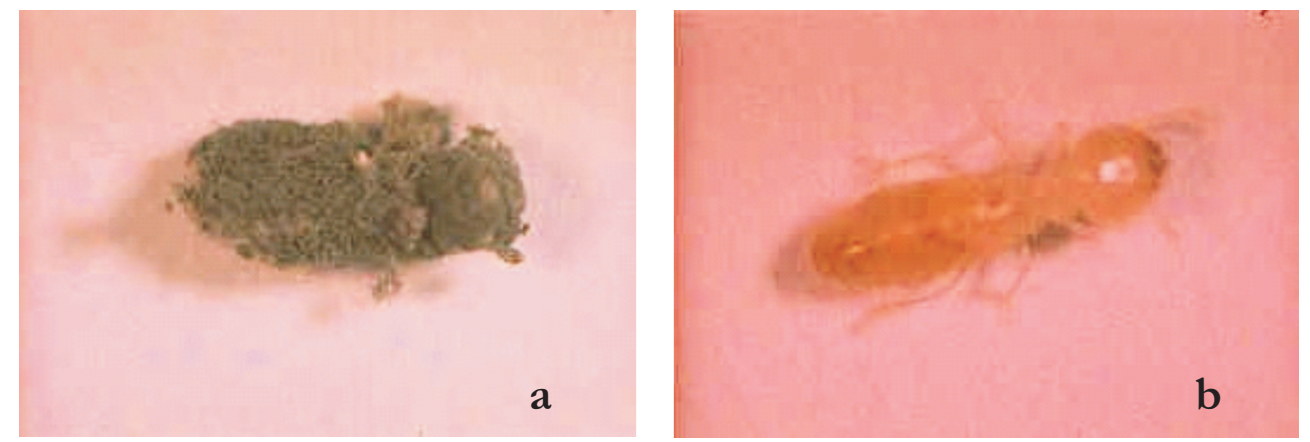

Gambar 1. Rayap yang terinfeksi jamur (a) dan rayap yang sehat (b)

Figure 1. An infected termite by fungus (a) and a healthy termite (b)

Perlakuan dengan jumlah rayap terinfeksi 50\% yang menyebabkan mortalitas rayap lebih dari 80\% ditunjukkan oleh isolat BGR (100\%), UGMp (95,5\%) dan SMG (89\%) (Tabel 2). Isolat yang lain rata-rata menyebabkan mortalitas rayap lebih rendah, yaitu $72,5 \%$ (UGMd), 66\% (BDG) dan 61\% (JBG). Berdasarkan hasil tersebut isolat BGR terlihat paling efektif untuk ditularkan ke dalam koloni rayap daripada isolat yang lain.

Efektivitas penularan yang tinggi dari jamur entomopatogen merupakan faktor utama untuk pengembangan jamur tersebut untuk pengendalian rayap dengan metode pengumpanan (Jones et al., 1996). Walaupun demikian, ada beberapa faktor yang mempengaruhi efektivitas penyebaran jamur patogen dalam koloni rayap, seperti kecenderungan rayap menghindari individu yang terinfeksi (Kramm et al., 1982) dan ketidakcukupan jumlah spora untuk menyebabkan mortalitas dalam jumlah yang cukup besar (Zoberi and Grace, 1990).

Spora dari isolat SMG, BGR dan UGMp dapat menempel pada kutikula rayap jauh lebih banyak daripada spora dari isolat UGMd, JMB dan BDG (Tabel 3). Jumlah spora yang menempel pada kutikula rayap ini akan berpengaruh terhadap penyebarannya dalam koloni. Semakin banyak spora yang dapat menempel pada rayap, semakin banyak pula jumlah spora yang dapat disebarkan ke koloni. 
Tabel 3. Jumlah spora yang menempel pada kutikula per ekor rayap Table 3. Numbers of spore attached to cuticle of a termite

\begin{tabular}{|c|c|}
\hline $\begin{array}{c}\text { Isolat } \\
(\text { Isolate })\end{array}$ & $\begin{array}{c}\text { Jumlah spora/rayap } \\
\text { (Number of spores termite) }\end{array}$ \\
\hline SMG & $6,7 \times 10^{5}$ \\
BGR & $6,45 \times 10^{5}$ \\
$\mathrm{UGM}_{\mathrm{p}}$ & $5,45 \times 10^{5}$ \\
$\mathrm{UGM}$ & $7,5 \times 10^{4}$ \\
$\mathrm{JMBG}$ & $2 \times 10^{5}$ \\
$\mathrm{BDG}$ & $6 \times 10^{4}$ \\
\hline
\end{tabular}

Jumlah spora yang menempel pada kutikula rayap tidak selalu berkorelasi dengan mortalitas, tetapi ditentukan juga oleh tingkat patogenisitas (virulensi) masing-masing isolat, seperti yang ditunjukkan pada isolat BGR dan SMG. Isolat BGR dapat menyebabkan mortalitas yang lebih tinggi walaupun rata-rata jumlah spora isolat SMG lebih banyak daripada isolat BGR. Diduga isolat BGR ini lebih virulen daripada yang lain.

Berdasarkan hasil penelitian ini, walaupun isolat BGR menunjukkan hasil yang paling efektif namun masih banyak faktor-faktor lain yang perlu dikaji lebih jauh seperti virulensi, mudah dan tidaknya untuk dibiakkan secara massal dan responnya terhadap kondisi lingkungan. Kombinasi dari berbagai uji laboratorium dan uji lapangan ini diharapkan dapat diperoleh isolat yang berpotensi untuk dikembangkan sebagai bahan bioinsektisida.

\section{KESIMPULAN}

Berdasarkan hasil penelitian diketahui bahwa efektivitas penularan yang tinggi ditunjukkan oleh isolat BGR, UGMp dan SMG yang secara berturut-turut dapat menyebabkan mortalitas 100, 95,5 dan 89\% pada perlakuan dengan 50\% rayap yang terinfeksi. Isolat BGR tampaknya paling efektif untuk ditularkan ke dalam koloni rayap.

\section{DAFTAR PUSTAKA}

Cloyd, R. A. 2002. The entomopathogenic fungus Metarbizium anisopliae. Midwest Biological Control News 6 (7). Website http://www.entomology.wisc.edu/ mbcn/kyf607.html. Diakses tanggal 27 Maret 2002.

Gabriel, B. P. 1968. Enzymatic activities of some Entomophorus Fungi. J. Invert. Pathol. 11: 70-81.

Gillespie, A. T. and E. R. Moorhouse. 1988. The use of fungi to control of agricultural and horticultural importance. Biotechnology of fungi for improving plant growth. 
Symposium of the British Mycological Society held at the University of Sussex September 1988. Cambridge University Press. Pp.: 56-84.

Grace, J. K. and M. H. Zoberi. 1992. Experimental evidence for transmission of Beauveria bassiana by Reticulitermes flavipes workers (Isoptera: Rhinotermitidae). Sociobiology 20 (1): 23-28.

Hanel, H. 1982. Selection of a fungus spesies, suitable for biological control of termite Nasutitermes exitious (Hill). Z. ang. Entomol. 94: 237-245.

Jones, W. E., J. K. Grace, and M Tamashiro. 1996. Virulence of seven isolates of Beauveria bassiana and Metarbizium anisopliae to Coptotermes formosanus (Isoptera: Rhinotermitidae). Environ. Entomol. 25 (2): 481-487.

Kramm, K. R., D. F. West, and P. G. Rockenbach. 1982. Termite pathogens: transfer of the entomopathogen Metarbizium anisopliae between Reticulitermes sp. termites. J. Invert. Pathol. 40:1-6.

Milner, R. J., J. A. Staples, and G. G. Lutton. 1997. The effect of humidity on germination and infection of termites by the hyphomycete, Metarbizium anisopliae. J. Invert. Pathol. 69: 6469.

Milner, R. J., J. A. Staples, and G. G. Lutton. 1998. The selection of an isolate of the hyphomycete fungus, Metarhizium anisopliae, for control of termites in Australia. Biol. Control, 11:240-247.

Steel, R. G. D. and J. H. Torrie. 1980. Principles and Procedures of Statistics, A Biometrical Approach (2 $2^{\text {nd }}$ edition). McGraw-Hill Book Company, New York. Pp 185-186.

Sukartana, P., A. Ismanto, W. Rumini and G. Sumarni. 2000. Susceptibility of three termite species to attack by entomopathogenic fungus Metarbizium anisopliae (Metschnikoff) Sorokin. For. Estate Crops Re. J. 1(2): 45-49.

Zoberi, M. H., and J. K. Grace. 1990. Isolation of the pathogen Beauveria bassiana from Reticulitermes flavipes (Isoptera: Rhinotermitidae). Sociobiology 16: 289-296. 


\title{
TEKNIK PEMBUATAN DAN SIFAT BRIKET ARANG DARI TEMPURUNG DAN KAYU TANAMAN JARAK PAGAR (Jatropha curcas L.)
}

\author{
(Technical Process and Characteristics of Charcoal Briquette \\ from Jatropha Curcas (Jatropha curcas L) Shell and Wood)
}

\author{
Oleh/By :
}

R. Sudradjat ${ }^{1)}$, D. Setiawan ${ }^{2)} \&$ H. Roliadi ${ }^{1)}$

\begin{abstract}
The aim of this research is to study the use of Jatropha curcas plant wastes in the form of seed shell and wood for making charcoal briquette, to increase economic feasibility of biodiesel manufacturing from jatropha curcas oil.

Treatments used were 200,400 , and $600 \mathrm{~kg} / \mathrm{cm}^{2}$ of compression, composition of raw materials were mixture with coconut shell of 0,25,50,75 and $100 \%$.

The results showed that char-briquette that was made from jatro-shell (100\%) showed higher value in density and compression strength, but lower in moisture, fixed carbon, calorific value from those of char-briquette from jatro-wood $(100 \%)$. On the other hand, char-briquette from jatro-wood was higher in moisture, fixed carbon and calorific value, but lower in density and compression strength. Mixture of those materials with coco-shell could increasing of fixed carbon and calorific value char-briquette from jatro-shell, and also increase density and compression strength of char-briquette from jatro-wood.

Some physico-chemical properties has been met the Japan Standard i.e: compression strength, moisture, volatile matter, fixed carbon (except char-briquette from jatro-shell of B 100/0). Density, ash content and calorific values were beyond the Japan Standard.
\end{abstract}

Keywords: Jatropha shell, jatropha wood, charcoal briquette,calorific value.

\begin{abstract}
ABSTRAK
Penelitian ini bertujuan untuk mempelajari pemanfaatan limbah dari tanaman jarak pagar berupa tempurung biji dan kayu untuk briket arang, yaitu dalam rangka meningkatkan kelayakan ekonomi pengusahaan minyak jarak pagar untuk biodisel.

Perlakuan dalam penelitian ini adalah pemberian tekanan 200, $400 \mathrm{dan} 600 \mathrm{~kg} / \mathrm{cm}^{2}$, serta komposisi campuran bahan baku (tempurung biji dan kayu jarak pagar) dengan tempurung kelapa 0,25 , 50, 75 dan $100 \%$.
\end{abstract}

\footnotetext{
${ }^{1)}$ Peneliti pada Pusat Penelitian dan Pengembangan Hasil Hutan, Bogor

2) Teknisi pada Pusat Penelitian dan Pengembangan Hasil Hutan, Bogor
} 
Hasil penelitian menunjukkan, briket yang dibuat dari tempurung biji jarak pagar (100\%) lebih tinggi di dalam kerapatan dan keteguhan tekan, tetapi lebih rendah di dalam kadar air, karbon terikat dan nilai kalor dari briket dari kayu jarak (100\%). Briket kayu jarak pagar (100\%) sebaliknya lebih tinggi dalam kadar air, karbon terikat dan nilai kalor, tetapi lebih rendah dalam kerapatan dan keteguhan tekan dari briket tempurung biji jarak pagar. Pencampuran dengan tempurung kelapa dapat meningkatkan karbon terikat dan nilai kalor briket dari tempurung biji jarak, serta meningkatkan kerapatan dan keteguhan tekan briket dari kayu jarak pagar.

Beberapa sifat fisiko-kimia briket arang telah memenuhi Standar Jepang yaitu: keteguhan tekan, kadar air, zat terbang, karbon terikat (kecuali briket arang dari tempurung biji jarak B 100/0). Sifat yang tidak memenuhi standar adalah: kerapatan, kadar abu dan nilai kalor (kecuali briket arang dari kayu jarak B 50/50).

Kata kunci: Tempurung biji jarak, kayu jarak pagar, briket arang, nilai kalor.

\section{PENDAHULUAN}

Cadangan bahan bakar fosil seperti minyak bumi, gas alam dan batu bara yang selama ini merupakan sumber utama energi jumlahnya semakin menipis (Indarti, 2001). Hal ini dikhawatirkan akan menyebabkan terjadinya kelangkaan bahan bakar dimasa yang akan datang. Menurut Abdullah (2002), Indonesia dalam waktu 10 - 20 tahun ke depan akan menjadi menjadi negara pengimpor minyak bersih (Net Oil Importing Country) jika kondisi ini tetap dibiarkan dan belum ada upaya-upaya yang signifikan. Demikian pula harga minyak bumi pada tahun 2005 tercatat memiliki rekor tertinggi dalam sejarah harga minyak dunia yaitu US\$ 70. Situasi ini memacu para peneliti untuk mencari sumber energi alternatif lain yang dapat dipulihkan dan secara potensial dapat dikembangkan di Indonesia, di antaranya adalah minyak dari biji tanaman jarak pagar (Jatropha curcas L). Lubis dan Sugiyono (1996), menyatakan bahwa sektor energi memiliki peran yang sangat penting dalam rangka mendukung kelangsungan proses pembangunan nasional.

Sudradjat et al. (2004), telah berhasil mengetahui cara proses dan karakteristik minyak (curcas oil) dan biodisel dari minyak jarak pagar. Dalam rangka mengantisipasi kemungkinan pengembangan tanaman ini secara luas di Indonesia sebagai bahan energi alternatif, maka perlu diketahui pemanfaatan bagian lain dari tanaman ini yang potensial sebagai bahan energi berupa briket arang. Berdasarkan penelitian sebelumnya diketahui bahwa tempurung biji jarak pagar memiliki porsi sekitar 25\% dari berat biji tersebut. Artinya dari produksi sekitar 3 ton biji kering/ha akan dihasilkan sekitar 1 ton tempurung, sedang kayu jarak dapat diperoleh dari pangkasan secara periodik setahun sekali. Sudradjat et al. (2004), menemukan bahwa tempurung jarak pagar sangat baik dan memenuhi standar kualitas internasional untuk dibuat arang aktif, sedang arang aktif kayunya cukup baik hanya untuk daya serap terhadap larutan (daya serap iod).

Pembuatan briket arang dapat dilakukan dengan cara penambahan perekat tapioka, dimana bahan baku diarangkan terlebih dahulu kemudian ditumbuk, dicampur perekat dan dicetak (kempa dingin) dengan sistim hidrolik manual dan selanjutnya dikeringkan (Pari, 2002). Perekat pati dalam bentuk cair sebagai bahan perekat menghasilkan briket arang bernilai rendah dalam hal kerapatan, keteguhan tekan, kadar abu dan zat mudah menguap, tetapi akan lebih tinggi dalam hal kadar air, karbon terikat dan nilai kalornya apabila 
dibandingkan dengan briket arang yang menggunakan perekat molase atau tetes tebu (Sudradjat, 1983). Menurut Sa'id (1996), apabila dibandingkan dengan arang, briket arang memiliki beberapa keunggulan antara lain dapat ditingkatkan kerapatannya, bentuk dan ukurannya dapat disesuaikan, tidak kotor, mudah diangkut dan praktis sebagai bahan bakar.

\section{METODOLOGI}

\section{A. Pembuatan Arang}

Pembuatan arang dilakukan dalam kiln berbentuk silinder berkapasitas 200 liter yang terbuat dari besi bekas drum. Pembuatan arang dari tempurung dilakukan secara terpisah dari pada kayunya. Selain tempurung dan kayu jarak pagar, sebagai pencampur dan penguat briket digunakan juga bahan baku lain yaitu tempurung kelapa.

Sebelum bahan baku dimasukkan ke dalam kiln, terlebih dahulu batang kayu/bambu berdiameter $10 \mathrm{~cm}$ dan panjang $100 \mathrm{~cm}$ ditempatkan tegak lurus pada titik tengah landasan kiln. Bahan baku dimasukkan sampai memenuhi dan memadati rongga kiln, selanjutnya kayu dicabut sehingga terbentuk lubang di bagian tengah kiln. Lubang ini adalah sebagai tempat bahan bakar umpan agar bahan baku terbakar dan menyala.

Bahan bakar umpan dinyalakan, dan setelah api menyala dengan stabil, kiln ditutup lalu cerobong asap dipasang pada bagian tengah kiln tersebut. Selanjutnya dilakukan pengaturan buka tutup lubang udara pada dinding kiln dan pembakaran terus dilakukan sampai asap yang keluar menipis dan berwarna kebiruan. Setelah itu lubang udara ditutup seluruhnya dan proses pirolisa tanpa udara dibiarkan terus berlanjut sampai sekitar 4 - 6 jam. Setelah cukup waktunya, arang dikeluarkan dan disiram dengan air. Prosedur ini dilakukan untuk setiap jenis bahan baku yaitu tempurung dan kayu jarak pagar serta tempurung kelapa.

\section{B. Pembuatan Serbuk dan Penyaringan}

Arang digiling dalam mesin giling kayu hingga terbentuk serbuk yang cukup, sedang yang sangat halus akan terbang dan ditangkap oleh siklun dan ditampung terpisah. Selanjutnya serbuk arang disaring dan hanya ukuran serbuk yang lolos 20 mesh dan tertampung pada 40 mesh yang digunakan untuk pembuatan briket arang.

\section{Pencampuran Perekat}

Perekat yang digunakan adalah tepung tapioka yang terlebih dahulu dibuat menjadi kanji yaitu dengan jalan mencampur dengan air secukupnya dan memanaskan di atas api sampai tepung berubah menjadi kanji. Banyaknya tepung tapioka adalah 5\% dari berat kering briket arang yaitu untuk berat briket sekitar 50 gram per buah. Selanjutnya kanji dicampur dengan serbuk arang sampai menjadi adonan yang merata.

\section{Pengempaan Briket}

Adonan dimasukkan ke dalam alat cetakan, kemudian dikempa menggunakan alat kempa hidraulik manual dengan variasi tekanan 200, 400 dan $600 \mathrm{~kg} / \mathrm{cm}^{2}$. Selanjutnya briket arang yang masih basah dikeringkan dalam oven pada suhu $60^{\circ} \mathrm{C}$ selama 24 jam. 


\section{E. Pengujian Kualitas}

Kualitas briket yang diuji meliputi sifat kimia dan fisik terdiri dari kadar air, kadar abu, kadar zat menguap, kadar karbon terikat, kerapatan, keteguhan tekan (ASTM, 1959) dan nilai kalor (ASTM, 1984).

\section{F. Rancangan Penelitian}

Jenis bahan baku yang digunakan adalah tempurung biji jarak pagar dan kayu jarak pagar. Untuk setiap jenis bahan baku diberikan perlakuan yaitu komposisi (A) persentase antara tempurung biji jarak pagar dengan tempurung kelapa serta persentase antara kayu jarak pagar dengan tempurung kelapa sebagai berikut:
$\mathrm{A} 1=\mathrm{BBJ}: \mathrm{TK}=0 \%: 100 \%$
$\mathrm{A} 4=\mathrm{BBJ}: \mathrm{TK}=75 \%: 25 \%$
$\mathrm{A} 2=\mathrm{BBJ}: \mathrm{TK}=100 \%: 0 \%$
$\mathrm{A} 5=\mathrm{BBJ}: \mathrm{TK}=25 \%: 75 \%$
$\mathrm{A} 3=\mathrm{BBJ}: \mathrm{TK}=50 \%: 50 \%$

di mana: $\mathrm{BBJ}=$ Bahan baku jarak (Tempurung atau kayu) dan TK $=$ Tempurung kelapa.

Untuk setiap taraf perlakuan diberikan variable perlakuan yaitu tekanan pengempaan (B) $: \mathrm{B} 1=200 \mathrm{~kg} / \mathrm{cm}^{2}, \mathrm{~B} 2=400 \mathrm{~kg} / \mathrm{cm}^{2}$ dan B3 $=600 \mathrm{~kg} / \mathrm{cm}^{2}$. Jumlah ulangan $3 \mathrm{kali}$. Jumlah total kombinasi perlakuan adalah 90. Rancangan penelitian yang digunakan adalah Rancangan Acak Berblok dengan Percobaan Faktorial, khususnya untuk parameter sifat fisis-mekanis briket yaitu kerapatan dan keteguhan tekan. Untuk parameter pengamatan sifat fisiko-kimia briket yaitu kadar air, abu, zat terbang, karbon terikat dan nilai kalor dilakukan analisis cara evaluasi tabulasi dan uji beda jarak Tukey atau uji beda nyata jujur (BNJ) dilanjutkan dengan nilai skoring (Steel \& Torrie, 1995).

\section{HASIL DAN PEMBAHASAN}

\section{A. Tempurung Biji Jarak Pagar}

\section{Kerapatan}

Hasil analisa sidik ragam menunjukan nilai kerapatan berkisar antara 0,19-0,21 g/ $\mathrm{cm}^{2}$ (Tabel 1). Hasil uji sidik ragam menunjukkan perlakuan persentase campuran tempurung kelapa dan perlakuan pengempaan berpengaruh nyata pada kerapatan (taraf kepercayaan 5\%). Hasil uji beda nyata jujur menunjukkan kerapatan tertinggi diperoleh dari bahan baku tempurung biji jarak 100\% dengan tekanan kempa $600 \mathrm{~kg} / \mathrm{cm}^{2}$, tempurung kelapa 100\% dengan tekanan kempa $600 \mathrm{~kg} / \mathrm{cm}^{2}$ dan campuran tempurung kelapa 50\% dengan tekanan kempa $600 \mathrm{~kg} / \mathrm{cm}^{2}$. Komposisi bahan baku dengan berbagai variasi tekanan kempa yang menghasilkan kerapatan rata-rata tertinggi adalah tempurung kelapa 100\%, serta sedikit lebih rendah kerapatan dihasilkan oleh tempurung biji jarak 100\% dan campuran tempurung kelapa $50 \%$. 
Tabel1. Nilai rata-rata dan hasil uji BNJ kerapatan briket tempurung biji jarak pagar Table 1. Average values and HSD-tests of density of jatropha shell briquette

\begin{tabular}{|c|c|c|c|c|}
\hline $\begin{array}{c}\text { Komposisi } \\
\text { (Composition), A }\end{array}$ & $\begin{array}{c}\text { Tekanan } \\
\text { (Compression) } \\
\mathrm{kg} / \mathrm{cm}^{2}, \mathrm{~B}\end{array}$ & $\begin{array}{c}\text { Kode perlakuan } \\
\text { (Treatment codes) } \\
\mathrm{T}\end{array}$ & $\begin{array}{l}\text { Nilai kerapatan } \\
\text { (Density), } \mathrm{g} / \mathrm{cm}^{2}\end{array}$ & $\begin{array}{l}\text { Skor } \\
(\text { Score })\end{array}$ \\
\hline A 1 & $\begin{array}{l}\text { B } 1 \\
\text { B } 2 \\
\text { B } 3\end{array}$ & $\begin{array}{l}\mathrm{T} 1 \\
\mathrm{~T} 2 \\
\mathrm{~T} 3\end{array}$ & $\begin{array}{c}0,19 \text { c } \\
0,20 \text { bc } \\
0,21 \quad a\end{array}$ & $\begin{array}{c}2 \\
2,5 \\
4\end{array}$ \\
\hline A 2 & $\begin{array}{l}\text { B } 1 \\
\text { B } 2 \\
\text { B } 3\end{array}$ & $\begin{array}{l}\mathrm{T} 4 \\
\mathrm{~T} 5 \\
\mathrm{~T} 6\end{array}$ & $\begin{array}{cc}0,20 & \text { abc } \\
0,21 & a b \\
0,21 & a\end{array}$ & $\begin{array}{c}3 \\
2,5 \\
4\end{array}$ \\
\hline A 3 & $\begin{array}{l}\text { B } 1 \\
\text { B } 2 \\
\text { B } 3\end{array}$ & $\begin{array}{l}\text { T } 7 \\
\text { T } 8 \\
\text { T } 9\end{array}$ & $\begin{array}{rr}0,19 & \mathrm{c} \\
0,20 & \mathrm{bc} \\
0,21 & \mathrm{a}\end{array}$ & $\begin{array}{c}2 \\
2,5 \\
4\end{array}$ \\
\hline A 4 & $\begin{array}{l}\text { B } 1 \\
\text { B } 2 \\
\text { B } 3\end{array}$ & $\begin{array}{l}\text { T } 10 \\
\text { T } 11 \\
\text { T } 12\end{array}$ & $\begin{array}{l}0,19 \quad \mathrm{c} \\
0,20 \text { abc } \\
0,20 \text { abc }\end{array}$ & $\begin{array}{l}2 \\
3 \\
3\end{array}$ \\
\hline A 5 & $\begin{array}{l}\text { B } 1 \\
\text { B } 2 \\
\text { B } 3\end{array}$ & $\begin{array}{l}\text { T } 13 \\
\text { T } 14 \\
\text { T } 15\end{array}$ & $\begin{array}{l}0,19 \quad \mathrm{c} \\
0,20 \mathrm{c} \\
0,20 \mathrm{ab}\end{array}$ & $\begin{array}{c}2 \\
2,5 \\
3,5\end{array}$ \\
\hline
\end{tabular}

Keterangan (Remarks) : Nilai skor total dihasilkan dari perhitungan menurut asumsi nilai skor a $=4$; b $=3 ; \mathrm{c}=2$ dan $\mathrm{d}=1$. A1 $=$ tempurung biji jarak pagar 100\%; A2 = tempurung kelapa $100 \% ; \mathrm{A} 3=$ tempurung biji jarak 50\% dan tempurung kelapa 50\%; A4 = tempurung biji jarak $75 \%$ dan tempurung kelapa 25\%; A5 = tempurung biji jarak $25 \%$ dan tempurung kelapa $75 \%$. B1 $=$ tekanan $200 \mathrm{~kg} / \mathrm{cm}^{2} ; \mathrm{B} 2=400 \mathrm{~kg} / \mathrm{cm}^{2}$ dan B3 $=600 \mathrm{~kg} / \mathrm{cm}^{2}$ (Total score achieved based on calculation with assumptions that a score $=4 ; b=3 ; c=2$ and $d=1 . A 1=J a t r o p h a$ seed shell 100\%;A2 = Coconut shell 100\%; $A 3=$ Jatropha seed shell: coco-shell $=50 \%: 50 \% ; A 4=$ Jatropha seed shell: coco-shell $=75 \%: 25 \% ; A 5=$ Jatropha seed shell: coco-shell $=25 \%: 75 \% . \quad B 1=$ compression of $200 \mathrm{~kg} / \mathrm{cm}^{2}, B 2=400 \mathrm{~kg} / \mathrm{cm}^{2}$, and B3 $=600 \mathrm{~kg} / \mathrm{cm}^{2}$, respectively).

\section{Keteguhan tekan}

Hasil analisa sidik ragam menunjukkan nilai keteguhan tekan berkisar antara 768,00 $1910,60 \mathrm{~kg} / \mathrm{cm}^{2}$ (Tabel 2). Hasil uji sidik ragam menunjukkan perlakuan persentase campuran tempurung kelapa dan perlakuan pengempaan berpengaruh nyata pada keteguhan tekan (taraf kepercayaan 5\%). Hasil uji beda nyata jujur menunjukkan keteguhan tekan tertinggi diperoleh dari bahan baku tempurung biji jarak 100\% dengan tekanan kempa $600 \mathrm{~kg} / \mathrm{cm}^{2}$, campuran dengan tempurung kelapa 50\% pada tekanan kempa 400 dan $600 \mathrm{~kg} / \mathrm{cm}^{2}$, dan campuran dengan tempurung kelapa $75 \%$ pada tekanan kempa $600 \mathrm{~kg} / \mathrm{cm}^{2}$. Komposisi bahan baku dengan berbagai variasi tekanan kempa yang menghasilkan keteguhan tekan rata- 
rata tertinggi adalah tempurung biji jarak 50\% dengan tempurung kelapa 50\%, serta sedikit lebih rendah adalah komposisi tempurung biji jarak 100\% dan campuran dengan tempurung kelapa $75 \%$.

\section{Sifat fisiko-kimia briket arang tempurung biji jarak pagar}

Hasil analisis sifat fisiko-kimia briket arang yang dibuat dari campuran tempurung biji jarak pagar dan tempurung kelapa terlihat pada Tabel3.

Tabel2. Nilai rata-rata dan hasil uji BNJ keteguhan tekan briket tempurung biji jarak pagar

Table 2. Average values and HSD-tests of compression strength of jatropha shell briquette

\begin{tabular}{|c|c|c|c|c|}
\hline $\begin{array}{c}\text { Komposisi } \\
\text { (Composition), A }\end{array}$ & $\begin{array}{c}\text { Tekanan } \\
\text { (Compression) } \\
\mathrm{kg} / \mathrm{cm}^{2}, \mathrm{~B}\end{array}$ & $\begin{array}{c}\text { Kode perlakuan } \\
\text { (Treatment codes) } \\
\mathrm{T}\end{array}$ & $\begin{array}{c}\text { Keteguhan } \\
\text { tekan (Compression } \\
\text { strength), } \mathrm{kg} / \mathrm{cm}^{2}\end{array}$ & $\begin{array}{l}\text { Skor } \\
\text { (Score) }\end{array}$ \\
\hline A 1 & $\begin{array}{ll}\text { B } & 1 \\
\text { B } & 2 \\
\text { B } & 3\end{array}$ & $\begin{array}{l}\text { T1 } \\
\text { T } 2 \\
\text { T } 3\end{array}$ & $\begin{array}{l}1553,30 \quad \mathrm{c} \\
1746,67 \mathrm{ab} \\
1820,00 \quad \mathrm{a}\end{array}$ & $\begin{array}{c}4 \\
5,5 \\
6\end{array}$ \\
\hline A 2 & $\begin{array}{l}\text { B } 1 \\
\text { B } 2 \\
\text { B } 3\end{array}$ & $\begin{array}{l}\text { T } 4 \\
\text { T } 5 \\
\text { T } 6\end{array}$ & $\begin{array}{ll}768,00 \mathrm{f} \\
854,60 \mathrm{f} \\
1169,70 \mathrm{f}\end{array}$ & $\begin{array}{l}1 \\
1 \\
2\end{array}$ \\
\hline A 3 & $\begin{array}{ll}\text { B } & 1 \\
\text { B } & 2 \\
\text { B } & 3\end{array}$ & $\begin{array}{l}\text { T } 7 \\
\text { T } 8 \\
\text { T } 9\end{array}$ & $\begin{array}{c}1570,60 \mathrm{bc} \\
1789,30 \mathrm{a} \\
1910,60 \mathrm{a}\end{array}$ & $\begin{array}{c}4,5 \\
6 \\
6\end{array}$ \\
\hline A 4 & $\begin{array}{l}\text { B } 1 \\
\text { B } 2 \\
\text { B } 3\end{array}$ & $\begin{array}{l}\text { T } 10 \\
\text { T } 11 \\
\text { T } 12\end{array}$ & $\begin{array}{l}10481,00 \mathrm{e} \\
1097,30 \mathrm{e} \\
1354,60 \mathrm{~d}\end{array}$ & $\begin{array}{l}2 \\
2 \\
3\end{array}$ \\
\hline A 5 & $\begin{array}{ll}\text { B } & 1 \\
\text { B } & 2 \\
\text { B } & 3\end{array}$ & $\begin{array}{l}\text { T } 13 \\
\text { T } 14 \\
\text { T } 15\end{array}$ & $\begin{array}{l}1508,00 \mathrm{~cd} \\
1745,30 \mathrm{ab} \\
1089,30 \mathrm{a}\end{array}$ & $\begin{array}{c}3,5 \\
5,5 \\
6\end{array}$ \\
\hline
\end{tabular}

Keterangan (Remarks) : Nilai skor total dihasilkan dari perhitungan menurut asumsi nilai skor a $=6$; $\mathrm{b}$ $=5 ; \quad \mathrm{c}=4 ; \mathrm{d}=3 ; \quad \mathrm{e}=2 \mathrm{dan} \mathrm{f}=1 . \quad \mathrm{A} 1=$ tempurung biji jarak pagar $100 \% ; \mathrm{A} 2=$ tempurung kelapa $100 \%$; A3; tempurung biji jarak 50\% dan tempurung kelapa 50\%; A4 $=$ tempurung biji jarak $75 \%$ dan tempurung kelapa $25 \%$; A $5=$ tempurung biji jarak $25 \%$ dan tempurung kelapa $75 \%$. B1 $=$ tekanan $200 \mathrm{~kg} / \mathrm{cm}^{2} ; \mathrm{B} 2=400 \mathrm{~kg} / \mathrm{cm}^{2}$ dan B3 $=600$ $\mathrm{kg} / \mathrm{cm}^{2}$ (Total score achieved based on calculation with assumptions that a score $=6 ; b=5 ; c=4 ; d=$ $3 ; e=2$ and $=1$. A1 = Jatropha seed shell 100\%;A2 = Coconut shell 100\%;A3= Jatropha seed shell: coco-shell $=50 \%: 50 \% ;$ A4 = Jatropha seed shell: coco-shell $=75 \%: 25 \% ;$ A5 = Jatropha seed shell: coco-shell $=25 \%: 75 \% . B 1=$ compression of $200 \mathrm{~kg} / \mathrm{cm}^{2}, B 2=400 \mathrm{~kg} / \mathrm{cm}^{2}$, and B3 $=600$ $\mathrm{kg} / \mathrm{cm}^{2}$, respectively). 
Tabel3. Nilai rata-rata dan hasil uji BNJ sifat fisiko-kimia briket arang dari tempurung jarak pagar

Table 3. Average values and HSD-tests of physico-chemical properties of jatropha shell briquette

\begin{tabular}{|c|c|c|c|c|c|c|}
\hline $\begin{array}{c}\text { Komposisi } \\
\text { (Composition) } \\
\text { A }\end{array}$ & $\begin{array}{c}\text { Tekanan } \\
(\text { Compression }) \\
\mathrm{kg} / \mathrm{cm}^{2} \\
\mathrm{~B}\end{array}$ & $\begin{array}{c}\text { Kadar air } \\
\text { (Moisture) } \\
\%\end{array}$ & $\begin{array}{c}\text { Zat terbang } \\
\text { (Volatile) } \\
\%\end{array}$ & $\begin{array}{c}\text { Kadar abu } \\
(A s h) \\
\%\end{array}$ & $\begin{array}{c}\text { Karbon } \\
\text { terikat } \\
(\text { F. carbon }) \\
\%\end{array}$ & $\begin{array}{l}\text { Nilai kalor } \\
\text { (Calorific } \\
\text { val.) } \\
\mathrm{cal} / \mathrm{g}\end{array}$ \\
\hline A 1 & $\begin{array}{l}\text { B } 1 \\
\text { B } 2 \\
\text { B } 3\end{array}$ & $\begin{array}{c}2,60 \mathrm{bc} \\
2,92 \mathrm{~b} \\
1,74 \mathrm{def}\end{array}$ & $\begin{array}{c}25,40 \mathrm{ab} \\
26,74 \mathrm{a} \\
26,65 \mathrm{a}\end{array}$ & $\begin{array}{c}17,17 \mathrm{a} \\
16,41 \mathrm{ab} \\
17,92 \mathrm{a}\end{array}$ & $\begin{array}{c}57,43 \mathrm{gh} \\
56,85 \mathrm{~h} \\
55,43 \mathrm{~h}\end{array}$ & $\begin{array}{l}4855 \mathrm{j} \\
4835 \mathrm{j} \\
4758 \mathrm{k}\end{array}$ \\
\hline Rata-rata: & & $2,42 \mathrm{a}$ & $26,26 \mathrm{a}$ & $17,17 \mathrm{a}$ & $56,57 \mathrm{e}$ & $4816 \mathrm{e}$ \\
\hline A 2 & $\begin{array}{l}\text { B } 1 \\
\text { B } 2 \\
\text { B } 3\end{array}$ & $\begin{array}{c}1,74 \mathrm{def} \\
2,21 \mathrm{~cd} \\
3,15 \mathrm{~b}\end{array}$ & $\begin{array}{c}19,76 \mathrm{e} \\
19,09 \mathrm{e} \\
20,06 \mathrm{de}\end{array}$ & $\begin{array}{l}2,97 \mathrm{f} \\
2,11 \mathrm{f} \\
3,05 \mathrm{f}\end{array}$ & $\begin{array}{l}77,27 \mathrm{ab} \\
79,80 \mathrm{a} \\
76,89 \mathrm{~b}\end{array}$ & $\begin{array}{l}6846 \mathrm{a} \\
6746 \mathrm{~b} \\
6601 \mathrm{c}\end{array}$ \\
\hline Rata-rata: & & $2,37 \mathrm{a}$ & $19,30 \mathrm{~d}$ & $2,71 \mathrm{~d}$ & $77,99 \mathrm{a}$ & $6731 \mathrm{a}$ \\
\hline A 3 & $\begin{array}{l}\text { B } 1 \\
\text { B } 2 \\
\text { B } 3\end{array}$ & $\begin{array}{c}1,20 \mathrm{f} \\
1,51 \mathrm{ef} \\
2,04 \mathrm{cde}\end{array}$ & $\begin{array}{l}24,44 \mathrm{~b} \\
23,76 \mathrm{bc} \\
21,81 \mathrm{~cd}\end{array}$ & $\begin{array}{c}13,02 \mathrm{~d} \\
13,78 \mathrm{~cd} \\
12,84 \mathrm{~d}\end{array}$ & $\begin{array}{c}62,54 \mathrm{f} \\
63,46 \mathrm{f} \\
68,35 \mathrm{ed}\end{array}$ & $\begin{array}{l}5727 \mathrm{f} \\
5576 \mathrm{~g} \\
5566 \mathrm{~g}\end{array}$ \\
\hline Rata-rata: & & $1,58 \mathrm{~b}$ & $23,34 \mathrm{c}$ & $13,21 \mathrm{~b}$ & $64,78 \mathrm{c}$ & $5623 \mathrm{c}$ \\
\hline A 4 & $\begin{array}{l}\text { B } 1 \\
\text { B } 2 \\
\text { B } 3\end{array}$ & $\begin{array}{c}1,88 \mathrm{de} \\
1,16 \mathrm{f} \\
4,23 \mathrm{a}\end{array}$ & $\begin{array}{l}25,00 \mathrm{ab} \\
25,33 \mathrm{ab} \\
25,33 \mathrm{ab}\end{array}$ & $\begin{array}{c}15,29 \mathrm{bc} \\
8,60 \mathrm{e} \\
17,28 \mathrm{a}\end{array}$ & $\begin{array}{c}59,81 \mathrm{~g} \\
66,07 \mathrm{e} \\
57,39 \mathrm{gh}\end{array}$ & $\begin{array}{l}5095 \mathrm{~h} \\
5027 \mathrm{hi} \\
4975 \mathrm{i}\end{array}$ \\
\hline Rata-rata: & & $2,42 \mathrm{a}$ & $25,22 \mathrm{~b}$ & $13,72 \mathrm{~b}$ & $61,09 \mathrm{~d}$ & $5032 \mathrm{~d}$ \\
\hline A 5 & $\begin{array}{l}\text { B } 1 \\
\text { B } 2 \\
\text { B } 3\end{array}$ & $\begin{array}{l}1,17 \mathrm{f} \\
1,48 \mathrm{ef} \\
1,55 \mathrm{ef}\end{array}$ & $\begin{array}{l}21,07 \mathrm{~d} \\
20,82 \mathrm{de} \\
20,89 \mathrm{de}\end{array}$ & $\begin{array}{l}7,95 \mathrm{e} \\
8,01 \mathrm{e} \\
8,55 \mathrm{e}\end{array}$ & $\begin{array}{c}70,98 \mathrm{c} \\
71,17 \mathrm{c} \\
70,56 \mathrm{~cd}\end{array}$ & $\begin{array}{l}6143 \mathrm{~d} \\
6092 \mathrm{~d} \\
6011 \mathrm{e}\end{array}$ \\
\hline Rata-rata: & & $1,40 \mathrm{~b}$ & $20,93 \mathrm{~d}$ & $8,17 \mathrm{c}$ & $70,90 \mathrm{~b}$ & $6082 \mathrm{~b}$ \\
\hline
\end{tabular}

Keterangan (Remarks) : Nilai skor total dihasilkan dari perhitungan menurut asumsi nilai skor a $=9$; $\mathrm{b}$ $=8 ; \mathrm{c}=7 ; \mathrm{d}=6 ; \mathrm{e}=5 ; \mathrm{f}=4 ; \mathrm{g}=3 ; \mathrm{h}=2$ dan $\mathrm{i}=1 . \mathrm{A} 1=$ tempurung biji jarak pagar $100 \% ;$ A2 $=$ tempurung kelapa $100 \% ; \quad$ A $3=$ tempurung biji jarak pagar $50 \%$ dan tempurung kelapa 50\%; A $4=$ tempurung biji jarak pagar $75 \%$ dan tempurung kelapa $25 \%$; A5 = tempurung biji jarak pagar 25\% dan tempurung kelapa 75\%. B1 = tekanan 200 $\mathrm{kg} / \mathrm{cm}^{2} ; \mathrm{B} 2=400 \mathrm{~kg} / \mathrm{cm}^{2}$ dan B3 $=600 \mathrm{~kg} / \mathrm{cm}^{2}$ (Total score achieved based on calculation with assumptions that a score $=9 ; b=8 ; c=7 ; d=6 ; e=5 ; f=4 ; g=3 ; b=2$ and $i=1$. A1 = Jatropha seed shell 100\%;A2 = Coconut shell 100\%;A3 = Jatropha seed shell: coco-shell $=50 \%: 50 \% ; A 4=$ Jatropha seed shell: coco-shell $=75 \%: 25 \% ; A 5=$ Jatropha seed shell: coco-shell $=25 \%: 75 \% . \quad B 1=$ compression of $200 \mathrm{~kg} / \mathrm{cm}^{2}, B 2=400 \mathrm{~kg} / \mathrm{cm}^{2}$, and B3 $=600 \mathrm{~kg} / \mathrm{cm}^{2}$, respectively). 
Hasil tabulasi menunjukkan kadar air berkisar antara 1,16 - 4,20\%. Hasil uji beda t-test menunjukkan kadar air terendah diperoleh dari campuran tempurung kelapa 75\%. Kombinasi bahan baku dan tekanan yang memberikan kadar air terendah diperoleh dari campuran tempurung kelapa $25 \%$ pada tekanan $400 \mathrm{~kg} / \mathrm{cm}^{2}$. Kadar zat terbang berkisar antara 19,09 - 26,74\%. Hasil uji beda t-test menunjukkan kadar zat terbang terendah diperoleh dari bahan baku tempurung kelapa 100\%. Kombinasi bahan baku dan tekanan yang memberikan kadar zat terbang terendah diperoleh dari tempurung kelapa 100\% pada tekanan $400 \mathrm{~kg} / \mathrm{cm}^{2}$. Kadar abu berkisar antara 2,11 - 17,90\%. Hasil uji beda t-test menunjukkan kadar abu terendah diperoleh dari bahan baku tempurung kelapa 100\%. Kombinasi bahan baku dan tekanan yang memberikan kadar abu terendah diperoleh dari tempurung kelapa $100 \%$ pada tekanan $400 \mathrm{~kg} / \mathrm{cm}^{2}$. Kadar karbon terikat berkisar antara 55,43-79,80\%. Hasil uji beda t-test menunjukkan kadar karbon terikat tertinggi diperoleh dari bahan baku tempurung kelapa 100\%. Kombinasi bahan baku dan tekanan yang memberikan kadar karbon terikat tertinggi diperoleh dari tempurung kelapa 100\% pada tekanan $400 \mathrm{~kg} / \mathrm{cm}^{2}$. Nilai kalor berkisar antara 4758 - $6846 \mathrm{kal} / \mathrm{g}$. Hasil uji beda t-test menunjukkan nilai kalor tertinggi diperoleh dari bahan baku tempurung kelapa 100\%. Kombinasi bahan baku dan tekanan yang memberikan nilai kalor tertinggi diperoleh dari tempurung kelapa 100\% pada tekanan $200 \mathrm{~kg} / \mathrm{cm}^{2}$.

\section{B. Kayu Jarak Pagar}

\section{Kerapatan}

Hasil analisa sidik ragam menunjukan nilai kerapatan berkisar antara 0,14-0,21 g/ cm². Hasil uji sidik ragam menunjukkan perlakuan persentase campuran tempurung kelapa dan perlakuan pengempaan berpengaruh nyata pada kerapatan (taraf kepercayaan 5\%). Hasil uji beda nyata jujur menunjukkan kerapatan tertinggi diperoleh dari bahan baku tempurung kelapa 100\% dengan tekanan kempa $600 \mathrm{~kg} / \mathrm{cm}^{2}$. Jenis bahan baku dengan berbagai variasi tekanan kempa yang memberikan nilai rata-rata kerapatan tertinggi adalah bahan baku tempurung kelapa $100 \%$. 
Tabel 4. Nilai rata-rata dan hasil uji BNJ kerapatan briket kayu jarak pagar Table 4. Average values and HSD-tetst of density of Jatropha wood briquette

\begin{tabular}{|c|c|c|c|c|}
\hline $\begin{array}{c}\text { Komposisi } \\
\text { (Composition) } \\
\text { A }\end{array}$ & $\begin{array}{l}\text { Tekanan } \\
\text { (Compression) } \\
\mathrm{kg} / \mathrm{cm}^{2}, \mathrm{~B}\end{array}$ & $\begin{array}{c}\text { Kode perlakuan } \\
\text { (Treatment codes) } \\
\mathrm{T}\end{array}$ & $\begin{array}{c}\text { Nilai kerapatan } \\
\text { (Density) } \\
\mathrm{g} / \mathrm{cm}^{2}\end{array}$ & $\begin{array}{c}\text { Skor } \\
\text { (Score) }\end{array}$ \\
\hline A 1 & $\begin{array}{ll}\text { B } & 1 \\
\text { B } & 2 \\
\text { B } & 3\end{array}$ & $\begin{array}{l}1 \\
2 \\
3\end{array}$ & $\begin{array}{l}0,14 \text { g } \\
0,15 \text { bc } \\
0,16 \text { ef }\end{array}$ & $\begin{array}{c}1 \\
5,5 \\
2,5\end{array}$ \\
\hline A 2 & $\begin{array}{l}\text { B } 1 \\
\text { B } 2 \\
\text { B } 3\end{array}$ & $\begin{array}{l}4 \\
5 \\
6\end{array}$ & $\begin{array}{r}0,20 \mathrm{ab} \\
0,21 \mathrm{a} \\
0,21 \quad \mathrm{a}\end{array}$ & $\begin{array}{c}6,5 \\
7 \\
7\end{array}$ \\
\hline A 3 & $\begin{array}{ll}\text { B } & 1 \\
\text { B } & 2 \\
\text { B } & 3\end{array}$ & $\begin{array}{l}7 \\
8 \\
9\end{array}$ & $\begin{array}{ll}0,17 & \mathrm{de} \\
0,18 & \mathrm{~cd} \\
0,18 & \mathrm{~cd}\end{array}$ & $\begin{array}{l}3,5 \\
4,5 \\
4,5\end{array}$ \\
\hline A 4 & $\begin{array}{ll}\text { B } & 1 \\
\text { B } & 2 \\
\text { B } & 3\end{array}$ & $\begin{array}{l}10 \\
11 \\
12\end{array}$ & $\begin{array}{ll}0,14 & g \\
0,15 & \mathrm{fg} \\
0,16 \mathrm{f}\end{array}$ & $\begin{array}{c}1 \\
1,5 \\
2\end{array}$ \\
\hline A 5 & $\begin{array}{ll}\text { B } & 1 \\
\text { B } & 2 \\
\text { B } & 3\end{array}$ & $\begin{array}{l}13 \\
14 \\
15\end{array}$ & $\begin{array}{l}0,17 \text { de } \\
0,18 \mathrm{~cd} \\
0,19 \mathrm{bc}\end{array}$ & $\begin{array}{l}3,5 \\
4,5 \\
5,5\end{array}$ \\
\hline
\end{tabular}

Keterangan (Remarks) : Nilai skor total dihasilkan dari perhitungan menurut asumsi nilai skor a $=7$; b $=6 ; \mathrm{c}=5 ; \mathrm{d}=4 ; \mathrm{e}=3 ; \mathrm{f}=2 \mathrm{dan} \mathrm{g}=1$. A1 = tempurung biji jarak pagar $100 \% ; \mathrm{A} 2=$ tempurung kelapa 100\%; A3 = tempurung biji jarak 50\% dan tempurung kelapa 50\%; A4 $=$ tempurung biji jarak 75\% dan tempurung kelapa 25\%; A5 = tempurung biji jarak 25\% dan tempurung kelapa 75\%. B1 = tekanan $200 \mathrm{~kg} / \mathrm{cm}^{2} ;$ B2 $=400 \mathrm{~kg} / \mathrm{cm}^{2}$ dan B3 = 600 $\mathrm{kg} / \mathrm{cm}^{2}$ (Total score achieved based on calculation with assumptions that a score $=7 ; b=6 ; c=5 ; d=$ 4; $e=3 ; f=2$ and $g=1$. A1 = Jatropha seed shell 100\%; A2 = Coconut shell 100\%; A3= Jatropha seed shell: coco-shell $=50 \%: 50 \% ; A 4=$ Jatropha seed shell: coco-shell $=75 \%: 25 \% ; A 5=$ Jatropha seed shell: coco-shell $=25 \%: 75 \%$. B1 $=$ compression of $200 \mathrm{~kg} / \mathrm{cm}^{2}, B 2=400 \mathrm{~kg} / \mathrm{cm}^{2}$, and $B 3=600 \mathrm{~kg} / \mathrm{cm}^{2}$, respectively).

\section{Keteguhan tekan}

Hasil analisa sidik ragam menunjukan nilai keteguhan tekan berkisar antara 576,00 $1169,70 \mathrm{~kg} / \mathrm{cm}^{2}$ (Tabel 5). Hasil uji sidik ragam menunjukkan perlakuan persentase campuran tempurung kelapa dan perlakuan pengempaan berpengaruh nyata pada keteguhan tekan (taraf kepercayaan 5\%). Hasil uji beda nyata jujur menunjukkan keteguhan tekan tertinggi diperoleh dari bahan baku tempurung biji jarak 100\% dengan tekanan kempa $600 \mathrm{~kg} / \mathrm{cm}^{2}$, komposisi dengan campuran tempurungh kelapa 50\% pada tekanan $400 \mathrm{dan} 600 \mathrm{~kg} / \mathrm{cm}^{2}$ dan komposisi dengan campuran tempurung kelapa 75\% pada tekanan $600 \mathrm{~kg} / \mathrm{cm}^{2}$. Komposisi bahan baku dengan berbagai variasi tekanan kempa yang menghasilkan keteguhan tekan tertinggi adalah komposisi dengan campuran tempurung kelapa 50\% dan 70\%. 
Tabel 5. Nilai rata-rata dan hasil uji BNJ keteguhan tekan briket kayu jarak pagar Table 5. Average values and HSD tests of compression strength of Jatropha wood briquette

\begin{tabular}{|c|c|c|c|c|}
\hline $\begin{array}{c}\text { Komposisi } \\
\text { Composition })\end{array}$ & $\begin{array}{c}\text { Tekanan } \\
\text { (Comprssion) } \\
\text { Kg/cm }\end{array}$ & $\begin{array}{c}\text { Kode perlakuan } \\
\text { (Treatments codes }) \\
\text { T }\end{array}$ & $\begin{array}{c}\text { Keteguhan tekan } \\
\text { (Compression strength) } \\
\mathrm{kg} / \mathrm{cm}^{2}\end{array}$ & $\begin{array}{c}\text { Skor } \\
(\text { Score })\end{array}$ \\
\hline A 1 & B 1 & 1 & $576,00 \mathrm{c}$ & 2 \\
& B 2 & 2 & $841,70 \mathrm{de}$ \\
$1070,70 \mathrm{ab}$ & 5,5 \\
& B 3 & 3 & $768,00 \mathrm{e}$ & 6 \\
\hline A 2 & B 1 & 4 & $854,60 \mathrm{de}$ & 1 \\
& B 2 & 5 & $1169,70 \mathrm{a}$ & 2 \\
\hline A 3 & B 3 & 6 & $633,30 \mathrm{f}$ & 4,5 \\
& B 1 & 7 & $752,00 \mathrm{e}$ & 6 \\
& B 2 & 8 & $1118,70 \mathrm{ab}$ & 6 \\
\hline B 3 4 & B 1 & 10 & $608,00 \mathrm{f}$ & 2 \\
& B 2 & 11 & $756,00 \mathrm{e}$ & 2 \\
& B 3 & 12 & $1046,70 \mathrm{bc}$ & 3 \\
\hline A 5 & B 1 & 13 & $606,70 \mathrm{f}$ & 3,5 \\
& B 2 & 14 & $937,30 \mathrm{~cd}$ & 5,5 \\
& B 3 & 15 & $1124,70 \mathrm{ab}$ & 6 \\
\hline
\end{tabular}

Keterangan (Remarks) : Nilai skor total dihasilkan dari perhitungan menurut asumsi nilai skor a $=6$; $\mathrm{b}$ $=5 ; \quad \mathrm{c}=4 ; \mathrm{d}=3 ; \quad \mathrm{e}=2$ dan $\mathrm{f}=1 . \quad \mathrm{A} 1=$ tempurung biji jarak pagar $100 \% ; \mathrm{A} 2=$ tempurung kelapa 100\%; A3 = tempurung biji jarak 50\% dan tempurung kelapa 50\%; A4 $=$ tempurung biji jarak $75 \%$ dan tempurung kelapa $25 \%$; A $5=$ tempurung biji jarak $25 \%$ dan tempurung kelapa $75 \%$. B1 $=$ tekanan $200 \mathrm{~kg} / \mathrm{cm}^{2} ; \mathrm{B} 2=400 \mathrm{~kg} / \mathrm{cm}^{2}$ dan B3 $=600$ $\mathrm{kg} / \mathrm{cm}^{2}$ (Total score achieved based on calculation with assumptions that a score $=6 ; \mathrm{b}=$ $5 ; \mathrm{c}=4 ; \mathrm{d}=3 ; \mathrm{e}=2$ and $\mathrm{f}=1 . \quad \mathrm{A} 1=$ Jatropha seed shell $100 \% ; \mathrm{A} 2=$ Coconut shell $100 \%$; A3 = Jatropha seed shell $:$ coco-shell $=50 \%: 50 \%$; A4 = Jatropha seed shell $:$ cocoshell $=75 \%: 25 \% ;$ A $5=$ Jatropha seed shell $:$ coco-shell $=25 \%: 75 \%$. B1 $=$ compression of $200 \mathrm{~kg} / \mathrm{cm}^{2}, \mathrm{~B} 2=400 \mathrm{~kg} / \mathrm{cm}^{2}$, and B3 $=600 \mathrm{~kg} / \mathrm{cm}^{2}$, respectively).

\section{Sifat fisiko-kimia briket kayu jarak pagar}

Hasil analisis sifat fisiko-kimia briket arang yang dibuat dari campuran kayu jarak pagar dan tempurung kelapa terlihat pada Tabel 6.

Hasil tabulasi menunjukkan kadar air berkisar antara 1,74 - 9,77\%. Hasil uji beda t-test yang memberikan kadar air terendah diperoleh dari bahan baku tempurung kelapa 100\%. Kombinasi bahan baku dan tekanan yang memberikan kadar air terendah diperoleh dari tempurung kelapa 100\% pada tekanan $200 \mathrm{~kg} / \mathrm{cm}^{2}$. Kadar zat terbang berkisar antara 16,63 $25,00 \%$. Hasil uji beda t-test yang memberikan kadar zat terbang terendah diperoleh dari 
campuran tempurung kelapa 25\%. Kombinasi bahan baku dan tekanan yang memberikan kadar zat terbang terendah diperoleh dari campuran tempurung kelapa 25\% pada tekanan 600 $\mathrm{kg} / \mathrm{cm}^{2}$. Kadar abu berkisar antara 2,11 - 12,83\%. Hasil uji beda t-test yang memberikan kadar abu terendah diperoleh dari bahan baku tempurung kelapa 100\%. Kombinasi bahan baku dan tekanan yang memberikan kadar abu terendah diperoleh dari tempurung kelapa 100\% pada tekanan $400 \mathrm{~kg} / \mathrm{cm}^{2}$. Kadar karbon terikat berkisar antara 62,17-79,80\%. Hasil uji beda t-test yang memberikan kadar karbon terikat tertinggi diperoleh dari bahan baku tempurung kelapa $100 \%$. Kombinasi bahan baku dan tekanan yang memberikan kadar karbon terikat tertinggi diperoleh dari tempurung kelapa 100\% pada tekanan $400 \mathrm{~kg} / \mathrm{cm}^{2}$. Nilai kalor berkisar antara 5014 - $6846 \mathrm{kal} / \mathrm{g}$. Hasil uji beda t-test yang memberikan nilai kalor tertinggi diperoleh dari bahan baku tempurung kelapa 100\%. Kombinasi bahan baku dan tekanan yang memberikan nilai kalor tertinggi diperoleh dari tempurung kelapa 100\% pada tekanan $200 \mathrm{~kg} / \mathrm{cm}^{2}$.

\section{Kualitas Briket Arang Menurut Standar}

Untuk dapat menilai kualitas briket arang dari tempurung biji jarak dan kayu jarak secara objektif, maka kualitas briket yang dihasilkan penelitian ini dibandingkan dengan standar. Briket arang yang dibandingkan dengan standar hanya briket arang yang menggunakan bahan baku tempurung biji atau kayu jarak 100\% (B 100/0) dan bahan tersebut dicampur dengan 50\% tempurung kelapa (B 50/50).

Tabel 7 menunjukkan, bahwa beberapa sifat telah memenuhi standar Jepang yaitu : keteguhan tekan, kadar air, zat terbang, karbon terikat (kecuali tempurung biji jarak B 100/0). Sifat yang tidak memenuhi standar adalah : kerapatan, kadar abu dan nilai kalor (kecuali kayu jarak B 50/50).

Apabila dibandingkan antara briket yang dibuat dari tempurung biji dan kayu jarak pagar murni tanpa dicampur dengan tempurung kelapa, maka briket dari tempurung biji lebih tinggi di dalam kerapatan $\left(0,21 \mathrm{~g} / \mathrm{cm}^{2}\right)$ dan keteguhan tekan $\left(1820 \mathrm{~kg} / \mathrm{cm}^{2}\right)$, tetapi lebih rendah dalam kadar air (1,7\%), karbon terikat $(56,85 \%)$ dan nilai kalor $(4855 \mathrm{kal} / \mathrm{g})$. Briket dari kayu jarak pagar lebih tinggi di dalam kadar air (5,87\%), karbon terikat $(66,01 \%)$ dan nilai kalor $(5750 \mathrm{kal} / \mathrm{g})$, tetapi lebih rendah dalam kerapatan $\left(0,16 \mathrm{~g} / \mathrm{cm}^{2}\right)$ dan keteguhan tekan $(1070,7$ $\left.\mathrm{kg} / \mathrm{cm}^{2}\right)$. 
Tabel 6. Nilai rata-rata sifat fisiko-kimia briket arang dari kayu jarak pagar Table 6. Average values of physico chemical of Jatropha wood-charcoal briquette

\begin{tabular}{|c|c|c|c|c|c|c|}
\hline $\begin{array}{c}\text { Komposisi } \\
\text { (Composition) } \\
\text { A }\end{array}$ & $\begin{array}{c}\text { Tekanan } \\
(\text { Compression }) \\
\mathrm{kg} / \mathrm{cm}^{2} \\
\mathrm{~B}\end{array}$ & $\begin{array}{c}\text { Kadar air } \\
\text { (Moisture) } \\
\%\end{array}$ & $\begin{array}{c}\text { Zat terbang } \\
\text { (Volatile) } \\
\%\end{array}$ & $\begin{array}{c}\text { Kadar abu } \\
(A s h) \\
\%\end{array}$ & $\begin{array}{c}\text { Karbon } \\
\text { terikat } \\
\text { (F. carbon) } \\
\%\end{array}$ & $\begin{array}{l}\text { Nilai kalor } \\
\text { (Calorific } \\
\text { val.), cal/g }\end{array}$ \\
\hline A 1 & $\begin{array}{ll}\text { B } & 1 \\
\text { B } & 2 \\
\text { B } & 3\end{array}$ & $\begin{array}{l}5,87 \\
6,07 \\
8,16\end{array}$ & $\begin{array}{l}25,00 \\
20,97 \\
22,19\end{array}$ & $\begin{array}{l}12,83 \\
12,14 \\
11,80\end{array}$ & $\begin{array}{l}62,17 \\
65,89 \\
66,01\end{array}$ & $\begin{array}{l}5250 \\
5191 \\
5014\end{array}$ \\
\hline Rata-rata: & & 6,07 & 22,39 & 12,25 & 61,69 & 5151 \\
\hline A 2 & $\begin{array}{l}\text { B } 1 \\
\text { B } 2 \\
\text { B } 3\end{array}$ & $\begin{array}{l}1,74 \\
2,21 \\
3,15\end{array}$ & $\begin{array}{l}19,76 \\
19,09 \\
20,06\end{array}$ & $\begin{array}{l}2,97 \\
2,11 \\
3,05\end{array}$ & $\begin{array}{l}77,27 \\
79,80 \\
76,89\end{array}$ & $\begin{array}{l}6846 \\
6766 \\
6601\end{array}$ \\
\hline Rata-rata: & & 2,36 & 19,20 & 2,71 & 77,98 & 6731 \\
\hline A 3 & $\begin{array}{l}\text { B } 1 \\
\text { B } 2 \\
\text { B } 3\end{array}$ & $\begin{array}{l}7,00 \\
8,56 \\
5,65\end{array}$ & $\begin{array}{l}22,08 \\
18,54 \\
20,45\end{array}$ & $\begin{array}{l}11,46 \\
10,84 \\
10,74\end{array}$ & $\begin{array}{l}66,46 \\
70,62 \\
68,81\end{array}$ & $\begin{array}{l}6308 \\
6276 \\
6252\end{array}$ \\
\hline Rata-rata: & & 7,07 & 20,35 & 11,01 & 68,63 & 6278 \\
\hline A 4 & $\begin{array}{l}\text { B } 1 \\
\text { B } 2 \\
\text { B } 3\end{array}$ & $\begin{array}{l}5,91 \\
5,99 \\
6,09\end{array}$ & $\begin{array}{l}20,35 \\
18,29 \\
16,63\end{array}$ & $\begin{array}{c}11,00 \\
10,09 \\
9,67\end{array}$ & $\begin{array}{l}68,65 \\
71,62 \\
73,74\end{array}$ & $\begin{array}{l}6151 \\
6131 \\
6122\end{array}$ \\
\hline Rata-rata: & & 5,99 & 18,42 & 10,25 & 71,33 & 6134 \\
\hline A 5 & $\begin{array}{l}\text { B } 1 \\
\text { B } 2 \\
\text { B } 3\end{array}$ & $\begin{array}{l}8,74 \\
9,77 \\
5,42\end{array}$ & $\begin{array}{l}20,37 \\
16,76 \\
18,05\end{array}$ & $\begin{array}{l}7,09 \\
6,89 \\
5,63\end{array}$ & $\begin{array}{l}72,54 \\
76,35 \\
76,32\end{array}$ & $\begin{array}{l}6673 \\
6672 \\
6552\end{array}$ \\
\hline Rata-rata: & & 7,97 & 18,39 & 6,53 & 75,07 & 6632 \\
\hline
\end{tabular}

Keterangan (Remarks) : A1 = kayu jarak pagar 100\%; A2 = tempurung kelapa 100\%; A3 = kayu jarak pagar 50\% dan tempurung kelapa 50\%; A4 = kayu jarak pagar 75\% dan tempurung kelapa $25 \%$; A5 = kayu jarak pagar 25\% dan tempurung kelapa 75\%. B1 = tekanan $200 \mathrm{~kg} / \mathrm{cm}^{2}$; $\mathrm{B} 2=400 \mathrm{~kg} / \mathrm{cm}^{2}$ dan B3 $=600 \mathrm{~kg} / \mathrm{cm}^{2}$ (A1 = Jatropha seed shell $100 \% ;$ A2 $=$ Coconut shell 100\%; A3 = Jatropha seed shell: coco-shel l $=50 \%: 50 \% ; A 4=$ Jatropha seed shell: coco-shell $=75 \%$ $: 25 \% ; A 5=$ Jatropha seed shell : coco-shell $=25 \%: 75 \%$. B1 = compression of $200 \mathrm{~kg} / \mathrm{cm}^{2} ; B 2=$ $400 \mathrm{~kg} / \mathrm{cm}^{2}$ and $B 3=600 \mathrm{~kg} / \mathrm{cm}^{2}$, respectively). 
Tabel 7. Kualitas briket arang dari tempurung biji dan kayu jarak pagar dibanding standar

Table 7. Quality of charcoal briquette from Jatropha's seed shell and wood compared to the standard

\begin{tabular}{|c|c|c|c|c|c|}
\hline \multirow{2}{*}{$\begin{array}{l}\text { Parameter } \\
\text { (Parametric) }\end{array}$} & \multicolumn{2}{|c|}{$\begin{array}{l}\text { Tempurung biji jarak } \\
\text { (Jatropha seed shell) }\end{array}$} & \multicolumn{2}{|c|}{$\begin{array}{c}\text { Kayu jarak } \\
\text { (Jatropha wood) }\end{array}$} & \multirow{2}{*}{$\begin{array}{c}\begin{array}{c}\text { Standar } \\
\text { (Standard) }\end{array} \\
\text { Jepang }\end{array}$} \\
\hline & B $100 / 0$ & B $50 / 50$ & B 100/0 & B $50 / 50$ & \\
\hline $\begin{array}{l}\text { Kerapatan (Density), } \\
\mathrm{g} / \mathrm{cm}^{2}\end{array}$ & 0,21 & 0,21 & 0,16 & 0,18 & $0,90-1,00$ \\
\hline $\begin{array}{l}\text { Keteguhan tekan } \\
\text { (Compression strength), } \\
\mathrm{kg} / \mathrm{cm}^{2}\end{array}$ & 1820 & 1910 & 1070 & 118 & $60-65$ \\
\hline Kadar air (Moisture), $\%$ & 1,74 & 1,55 & 5,87 & 5,65 & $6-8$ \\
\hline Kadar abu $(A s h), \%$ & 16,40 & 12,80 & 11,80 & 10,70 & $3-6$ \\
\hline $\begin{array}{l}\text { Zat terbang } \\
\text { (Vol. matter), \% }\end{array}$ & 19,09 & 23,70 & 20,90 & 18,50 & $15-30$ \\
\hline $\begin{array}{l}\text { Karbon terikat } \\
(\text { F. carbon }), \%\end{array}$ & 57,40 & 65,40 & 66,01 & 70,60 & $60-80$ \\
\hline $\begin{array}{l}\text { Nilai kalor } \\
\text { (Calorific value), } \mathrm{kal} / \mathrm{g}\end{array}$ & 4855 & 5727 & 5250 & 6276 & $6000-7000$ \\
\hline
\end{tabular}

\section{KESIMPULAN DAN SARAN}

1. Briket yang dibuat dari tempurung biji jarak pagar (100\%) lebih tinggi di dalam kerapatan dan keteguhan tekan, tetapi lebih rendah di dalam kadar air, karbon terikat dan nilai kalor briket kayu jarak (100\%). Briket kayu jarak pagar (100\%) sebaliknya lebih tinggi dalam kadar air, karbon terikat dan nilai kalor, tetapi lebih rendah dalam kerapatan dan keteguhan tekan dari briket tempurung biji jarak pagar.

2. Pencampuran dengan tempurung kelapa dapat meningkatkan karbon terikat dan nilai kalor briket dari tempurung biji jarak, serta meningkatkan kerapatan dan keteguhan tekan briket dari kayu jarak pagar.

3. Untuk briket dari tempurung biji jarak, kerapatan tertinggi diperoleh dari bahan baku tempurung biji jarak 100\% dengan tekanan kempa $600 \mathrm{~kg} / \mathrm{cm}^{2}$, tempurung kelapa 100\% dengan tekanan kempa $600 \mathrm{~kg} / \mathrm{cm}^{2}$ dan campuran tempurung kelapa 50\% dengan tekanan kempa $600 \mathrm{~kg} / \mathrm{cm}^{2}$. Untuk briket dari kayu jarak pagar, kerapatan tertinggi diperoleh dari bahan baku tempurung kelapa 100\% dengan tekanan kempa $600 \mathrm{~kg} / \mathrm{cm}^{2}$.

4. Untuk briket dari tempurung biji jarak, keteguhan tekan tertinggi diperoleh dari bahan baku tempurung biji jarak 100\% dengan tekanan kempa $600 \mathrm{~kg} / \mathrm{cm}^{2}$, campuran dengan 
tempurung kelapa 50\% pada tekanan kempa $400 \mathrm{dan} 600 \mathrm{~kg} / \mathrm{cm}^{2}$, serta campuran dengan tempurung kelapa 75\% pada tekanan kempa $600 \mathrm{~kg} / \mathrm{cm}^{2}$. Untuk briket dari kayu jarak pagar, keteguhan tekan tertinggi diperoleh dari bahan baku tempurung biji jarak 100\% dengan tekanan kempa $600 \mathrm{~kg} / \mathrm{cm}^{2}$, komposisi dengan campuran tempurung kelapa 50\% pada tekanan 400 dan $600 \mathrm{~kg} / \mathrm{cm}^{2}$, serta komposisi dengan campuran tempurung kelapa $75 \%$ pada tekanan $600 \mathrm{~kg} / \mathrm{cm}^{2}$.

5. Beberapa sifat fisiko-kimia telah memenuhi Standar Jepang yaitu : keteguhan tekan, kadar air, zat terbang dan karbon terikat (kecuali tempurung biji jarak B 100/0). Sifat fisikokimia yang tidak memenuhi standar : kerapatan, kadar abu dan nilai kalor (kecuali kayu jarak B 50/50).

6. Perlu dilakukan penelitian lebih lanjut mengenai peningkatan kualitas briket arang dari tempurung dan kayu jarak pagar dengan menitikberatkan pada aspek kadar perekat yang digunakan.

\section{DAFTAR PUSTAKA}

Abdullah, K. 2002. Biomass Energy Potential and Utilization in Indonesia. Institut Pertanian Bogor.

ASTM. 1959. ASTM Standard. Coal and Coke D-5. American Society for Testing and Materials. Philadephia.

. 1984. ASTM Standard. Laboratory Sampling and Analysis Coal and Coke. American Society for Testing and Materials. Philadephia.

Indarti. 2001. Country Paper : Indonesia. Regional Seminar on Commercialization of Biomass Technology, 4 - 8 June, Guangzhou. China.

Lubis, A. dan A. Sugiyono. 1996. Overview of energy planning in Indonesia. Technical Comittee Meeting to Asses and Compare the Potential Rule of Nuclear Power and Other Options in Alleviating Health and Environental Impacts from Electricity Generation, 14 - 16 October, Vienna, Austria.

Pari, G. 2002. Teknologi alternatif pemanfaatan limbah industri pengolahan kayu. Makalah Falsafah Sains. Program Pasca Sarjana IPB. Bogor.

Sa'id, E.G. 1996. Penanganan dan pemanfaatan limbah kelapa sawit. Trubus Agriwidya. Bogor.

Steel, D.L and J.H. Torrie. 1995. Prinsip dan Prosedur Statistik. Terjemahan, Gramedia. Jakarta.

Sudradjat, R. 1983. Pengaruh bahan baku, jenis perekat dan tekanan kempa terhadap kualitas briket arang. Laporan Penelitian Hasil Hutan No. 165. Pusat Penelitian Hasil Hutan. Bogor.

Anggorowati dan D. Setiawan. 2004. Pembuatan arang aktif dari kayu jarak pagar (Jatopha curcas L.). Jurnal Penelitian Hasil Hutan. 23(4): 299 - 315. Pusat Penelitian dan Pengembangan Hasil Hutan. Bogor. 